Columbia Law School

Scholarship Archive

1982

\title{
The Case Against Shark Repellent Amendments: Structural Limitations on the Enabling Concept
}

Ronald J. Gilson

Columbia Law School, rgilson@law.columbia.edu

Follow this and additional works at: https://scholarship.law.columbia.edu/faculty_scholarship

Part of the Business Organizations Law Commons

\section{Recommended Citation}

Ronald J. Gilson, The Case Against Shark Repellent Amendments: Structural Limitations on the Enabling Concept, 34 StAN. L. ReV. 775 (1982).

Available at: https://scholarship.law.columbia.edu/faculty_scholarship/984

This Article is brought to you for free and open access by the Faculty Publications at Scholarship Archive. It has been accepted for inclusion in Faculty Scholarship by an authorized administrator of Scholarship Archive. For more information, please contact scholarshiparchive@law.columbia.edu. 


\title{
The Case Against Shark Repellent Amendments: Structural Limitations on the Enabling Concept
}

\author{
Ronald J. Gilson*
}

The tactical history of the tender offer movement resembles an unrestrained arms race. ${ }^{1}$ Faced with offeror assaults in the form of Saturday night specials, various types of bear-hugs, godfather offers, and block purchases, ${ }^{2}$ target management responded with equally in-

* A.B., Washington University, St. Louis; J.D., Yale University. Associate Professor of Law, Stanford University. The research for this article was supported by the Stanford Legal Research Fund, made possible by a bequest from the Estate of Ira S. Lillick, and by gifts from Roderick E. and Carla A. Hills and other friends of the Stanford Law School.

I am grateful to Lee Bollinger, Richard Buxbaum, Louis Cohen, Melvin Eisenberg, Bruce Gitelson, Thomas Jackson, Robert Mnookin, A. Mitchell Polinsky, Gerald Rosberg, and Kenneth Scott for their helpful comments on an earlier draft of this article. Errors, of course, remain mine. I am also grateful to Christopher Lunding for access to his extensive file of shark repellent amendments.

1. The military metaphor has become common in discussion of tender offer strategy. The most elaborate and imaginative development of this theme is Lipton and Steinberger's treatment of a takeover battle as a feudal war of the Middle Ages. See 1 M. LipToN \& E. STEINBERgER, TAKEOVERS AND FREEZEOUTS vii-viii (1978).

2. A Saturday night special is an offer made without prior consultation with the target and left open for only the minimum offering period. Id. at 39. The technique is intended to minimize the target's response time and to maximize the pressure on target shareholders. A conflict exists as to the origin of the term. Compare Troubh, Purchased Affection: A Primer on Cash Tender Offers, HARv. Bus. REv., July-Aug. 1976, at 79, 86 (term arose out of General Cable Corporation's attempt to acquire Microdot, Inc.), with Gurwin, The Scorched Earth Poligy, THE INSTITUTIONAL INVESTOR, June 1979, at 33, 34 (term attributed to public relations man Richard Cheney as an effort to convey the impression that an offer by Colt Industries was "cheap and that it went off quickly" (quoting Cheney)).

There are at least three variants of the bear-hug. In a classic bear-hug, the target is notified of the offeror's intention to make a tender offer at a specified price but without a concurrent public announcement. The strong bear-hug contemplates a simultaneous public announcement of the offer and attempts to negotiate for the target's cooperation. The super strong bear-hug adds to this the threat that opposition or delay by the target will result in a decrease in the offering price. E.g. A. FleIsCher, Tender OfFERs: Defenses, Responses, AND PlanNing 57-59 (1981); Greenhill, Structuring an Offer, 32 Bus. LAW. 1305, 1308 (1977).

A godfather offer is a "cash offer so rich that . . . the directors do not believe . . . they can reasonably refuse it." A. Fleischer, supra, at 103 n.291.

A block purchase is the preoffer accumulation of a significant position in the target's stock, meant both to exert leverage over the target and to prevent others from joining the bidding. 
triguing defensive tactics: the black book, reverse bear-hug, sandbag, show stopper, white knight, and, drawing directly on military jargon, the scorched earth. ${ }^{3}$ But however varied the labels given particular defensive strategies, they share the common characteristic of being responsive: They are available only after an offer is made and the battle for the target's independence joined. From the target's perspective, what was missing from the defensive arsenal was a deterrent-a tactic that would convince a potential offeror not even to attempt the attack, thereby not only saving the target the substantial costs associated with tender offer conflicts ${ }^{4}$ but, more importantly, eliminating the not insubstantial risk that all defenses would fail and the offer prove successful. ${ }^{5}$

E.g., Freund \& Easton, The Three-Piece Suitor: An Allemative Approach to Negotiated Corporate Acquisitions, 34 Bus. LAw. 1679, 1683 (1979). A preoffer accumulation of target stock also allows an unsuccessful offeror to recover at least some of the costs incurred in connection with the offer if a competing bidder is ultimately successful. See Gilson, $A$ Structural Approach to Corporations: The Case Against Defensive Tactics in Tender Offers, 33 StAN. L. REv. 819, 871-72 (1981).

3. A black book is an outline of the actions to be taken if a tender offer should occur. E.g., P. Davey, Defenses Against Unnegotiated Gash Tender Offers 2 (1977).

In a reverse bear-hug, a target responds to an offer by expressing a willingness to negotiate a friendly acquisition but at a price far in excess of that proposed by the offeror. A. FLEISCHER, supra note 2, at 63-64; $1 \mathrm{M}$. LIPTON \& E. STEINBERGER, supra note 1 , at 71.

A sandbag is intended to delay the making of a tender offer following a bear-hug. The target agrees to negotiate, but draws out the negotiations as long as possible. Id. at 16; Reuben \& Elden, How to be a Target Company, 23 N.Y.L. ScH. L. REv. 423, 441 (1978).

A show stopper is a lawsuit by the target seeking a permanent injunction barring the offer. The most common claim is that the acquisition of the target will violate the antitrust laws. E.g. , Pargas, Inc. v. Empire Gas Corp., 423 F. Supp. 199 (D. Md.), affd per curiam, 546 F.2d 25 (4th Cir. 1976). Courts have become increasingly less sympathetic to these claims because of their obvious strategic character. See, e.g., Missouri Portland Cement Co. v. Cargill, Inc., 498 F.2d 851 (2d Cir.), cert. denied, 419 U.S. 883 (1974); Wachtell, Special Tender Offer Litigation Tactics, 32 Bus. LAw. 1433, 1438 (1977).

A while knight is a third party to whom the target turns for a friendly acquisition as an alternative to the tender offer. Because this tactic results in the loss of the target's independence, one may question whether it is a defensive tactic or merely a negotiated surrender.

A scorched earth defense seeks to convince the offeror that the target's defense will be so vigorous as to reduce its value to the offeror. Gurwin, supra note 2. One example of this approach was Houghton Mifflin's success in causing its authors to advise an offeror that they would sever their relationships with the target if the offer was successful. Id. at 37.

4. The out-of-pocket costs involved in contested tender offers can amount to the tens of millions of dollars. See Gilson, supra note 2, at $841 \mathrm{n} .86$. Any measure of the cost of management time would substantially increase these figures.

5. Recent statistics indicate that only a minority of target corporations remain independent following a tender offer. A study of 69 tender offers made between 1976 and 1979 found that only 13 targets (19\%) were able to maintain their independence. Fleischer, Business Judgment Rule Protecls Takeover Targets, Legal Times Wash., Apr. 14, 1980, at 15, col. 1 (reporting Goldman Sachs study). Data covering the period from 1956 through June 30, 1979, show a postoffer independence rate of only 20\%. Austin, Tender Offer Update: 1978-1979, MERGERS \& ACQUisitions, Summer 1980, at 13, 16 (table 4). 
Shark repellent amendments are intended to fill this gap in a prospective target's defenses. The idea is to amend the target's articles of incorporation to make it a less desirable or more difficult acquisition, and thereby to encourage the "shark" to seek a more appetizing or more easily digested alternative. ${ }^{6}$ If successful, however, the tactic is not without cost. To the extent that shark repellent amendments deter potential offerors, they also have the unavoidable effect of preventing shareholder access to offers made at substantial premiums over market price, and at the same time insulating incumbent management from the principal mechanism by which they might be dislodged unwillingly from their positions.

Despite this clear conflict of interest between management and shareholder, ${ }^{7}$ and the extensive literature cataloguing the variety of shark repellent amendments which have been devised, there has been little discussion of the validity of these amendments under state cor-

6. The literature concerning shark repellent amendments is extensive. E.g., E. ARANOW \& H. Einhorn, Tender OfFers for Corporate Control 223 (1973); E. ARaNow, H. Einhorn \& G. Berlstein, Developments in Tender OfFers for Corporate Control 194-96 (1977); P. DAVEY, supra note 3, at 13-14; A. FleISCHER, supra note 2, at 6; $1 \mathrm{M}$. LIPTON \& E. STEINBERGER, supra note 1, at 265; Black \& Smith, Antitakeover Charter Provisions: Defending Self-Help for Takeover Targets, 36 WASH. \& LEE L. REV. 699 (1979); Cohen, Takeover Bids: How Target Companies Fight Back, Fun. ANALysts J., Jan.-Feb. 1970, at 26; Hochman \& Folger, Deflecting Takeovers: Charter and By-law Techniques, 34 Bus. LAw. 537 (1979); Mullaney, Guarding Against Takeovers-Defensive Charter Provisions, 25 Bus. LAW. 1441 (1970); Rose \& Collins, Porcupine Proposals, 12 REv. SEC. REg. 977 (1979); Schmults \& Kelly, Cash Take-over Bids-Defense Tactics, 23 Bus. Law. 115 (1967); Smith, Fair Price and Redemption Rights: New Dimensions in Defense Charter Provisions, 4 DEL. J. CORP. L. 1 (1978); Yoran, Advance Defensive Tactics Against Takeover Bids, 21 AM. J. COMP. L. 531 (1973).

7. Commentators were quick to identify shark repellents when they first appeared. See, e.g. , Cary, Corporate Devices Used to Insulate Management from Allack, 25 Bus. LAw. 839 (1970); Wetzel, Defensive Tactics-Who are the Goodies and Who are the Baddies?, 25 Bus. LAw. 545 (1970). Further, the Securities and Exchange Commission has required management proxy statements to disclose the potential for shareholder injury "[s]ince at least 1969." Securities Exchange Act Release No. 15,230, Disclosure in Proxy and Information Statements; Antitakeover or Similar Proposals, reprinted in [1978 Transfer Binder] FED. SEC. L. REP. (CCH) If 81,748 , at 80,985 (Oct. 13,1978 ). The thrust of the required disclosure is to provide shareholders a description of the proposed amendments' effects on control of the corporation and on the likelihood of potential offers. For a detailed discussion of this release, see Black \& Smith, supra note 6 .

The SEC again showed its concern over shark repellent amendments in Securities Act Release No. 6159, Securities Exchange Act Release No. 16,385, Proposed Amendments to Tender Offer Rules, reprinted in [1979-1980 Transfer Binder] FED. SEC. L. REP. (CCH) If 82,374 (Nov. 29, 1979), where the Commission noted that shark repellent amendments "appear[ed] to be inconsistent with the protection of investors," and requested comment with respect to both the impact of such amendments and "the need for and type of rulemaking action which should be taken by the Commission." Id at 82,614 . 
poration statutes. ${ }^{8}$ Even where courts and commentators have raised the issue, the inquiry either has been conclusory, ${ }^{9}$ has been diverted to debate over the character of management's motive for seeking to prevent a potential shift in corporate control, ${ }^{10}$ or has been trivialized by limitation to technical analysis of the statutory language governing charter amendments and shareholder voting. ${ }^{11}$

In this article, I argue that these approaches cannot provide an intelligent resolution of the conflict between management and shareholders that is inherent in shark repellent amendments. I have elsewhere argued that the validity of tender offer defensive tactics generally turns on the structure of the modern corporation, the skeleton of which is described in the typical state corporation statute, but whose substance is completed by extrastatutory influences deriving from relationships between those participating in the corporation and from the markets in which they and the corporation function. ${ }^{12}$ Examination of that structure yielded a principle-that decisions concerning tender offers must be made by shareholders ${ }^{13}$ - which I formalized in a rule barring, at any time after target management "has reason to believe that a tender offer may be made," any action that "could interfere with the success of the offer or result in the shareholders of the target company being denied the opportunity to tender their shares."14 Shark repellent amendments, however, pose a number of problems not presented by defensive tactics generally that not only make it impossible to apply this rule to them, but also raise the question of whether a structural approach can be applied at all.

8. Direct judicial consideration of the validity of shark repellent amendments themselves is limited to three cases. See notes 129-31 infra and accompanying text. With respect to judicial consideration of management's role in the adoption of these provisions, "[c]ase law guidance as to the standards of conduct for directors in recommending or adopting sharkrepellent provisions is almost nonexistent." A. FLEISCHER, supra note 2, at 24-4. While commentators have on occasion raised one or the other issue, see, e.g., Cary, supra note 7, Smith, supra note 6 , discussion has been largely cursory.

9. "Most of these types of amendments are contrary to the basic principles of corporate democracy." E. ARANOw, H. EINHORN \& G. BERLSTEIN, supra note 6, at 195. Even economic analysis of tender offer regulation has been moved to hyperbole by the shark repellent phenomenon. See Fischel, Efficient Capital Market Theory, the Market for Corporate Control, and the Regulation of Cash Tender Offers, 57 TEx. L. REv. 1, 30 (1978) ("These defensive charter amendments seem repugnant to the most basic principles of corporate democracy.").

10. A. FLEISCHER, supra note 2, at 24-5 to -26 .

11. See notes $132-72$ infra and accompanying text.

12. Gilson, supra note 2 , at $845-48$.

13. Id .; accord, Easterbrook \& Fischel, The Proper Role of a Target's Management in Responding to a Tender Offer, 94 HARV. L. REV. 1161 (1981) (rule of managerial passivity).

14. Gilson, supra note 2, at 878-79. What constitutes "interference" and the role which remains for target management are considered in detail in id. at 865-75. 
The problem with applying my prohibitory rule is that the same factor that accounts for shark repellent amendments' popularitytheir potential for deterrence-also counsels their adoption before an actual offer surfaces. Because the rule does not operate until the time of an offer, it cannot apply to the great majority of shark repellent amendments. But while this problem merely suggests applying the structural approach earlier in the process, another aspect of shark repellent amendments presents a substantial barrier to applying it at all. Unlike other defensive tactics, about which the corporate statute is silent, the crucial characteristic of shark repellent amendments-a supermajority vote requirement-seems to be expressly authorized by typical corporate statutes. ${ }^{15}$ Moreover, the impact of direct statutory authorization is magnified by the fact that shark repellent amendments are for the most part adopted by the vote of the shareholders. As a result, they come not only with a statutory invitation, but with the additional blessing that common enabling-type statutes accord "contractual" provisions. ${ }^{16}$

Shark repellent amendments thus pose two types of questions for a structural approach to corporate law. First, can this approach deal with the problem of statutory construction posed by such express authorization? Second, and more generally, can a structural approach provide a guide to statutory construction that coherently limits the freedom offered by an enabling approach to corporate legislationthe freedom to "put the arrangements for the allocation of risk, control, profit, and residual ownership on a free contract basis"? ${ }^{17}$ In this sense, shark repellent amendments pose the most difficult case: Are limits appropriate even where the statute directly authorizes a provision that the shareholders specifically have approved?

Part I of this article surveys the phenomenon of shark repellent amendments and considers whether they can be expected to provide the deterrent promised by their proponents. Part II critically examines traditional approaches to their validity. Having argued that these are seriously deficient, I demonstrate in Part III that shark repellent amendments are inconsistent with the structure of the modern public corporation. Part IV then considers the fact that shark repellent amendments will have been approved by the shareholders, and Part V suggests a means to determine which charter provisions

15. See notes $132-53$ infra and accompanying text.

16. See text accompanying notes 193-206 infra.

17. Latty, Why Are Business Corporation Laws Largely "Enabling"?, 50 CORNELL L.Q. 599, 601 (1965); see text accompanying notes 220-29 infra. 
should be subject to the structural prohibition. Finally, in Part VI I sketch a structural approach to limiting the otherwise blank check an enabling-type statute provides to redesign that structure. The reality of electoral control by management in public corporations requires such a limit; a structural approach can provide one.

\section{A Survey of the Phenomenon}

Shark repellent amendments and the theories behind their asserted deterrent effect fall into three general categories. A first group of amendments is directed at impeding a successful offeror from taking control of the target's board of directors by protecting the incumbency of existing management. A second group is directed at making more difficult a second-step freezeout merger which eliminates any nontendering shareholders. The third group is intended to deprive the offeror of control over the total cost of the acquisition by specifying the price to be paid nontendering shareholders in a freezeout transaction or, at the extreme, by allowing nontendering shareholders to require the offeror to purchase their shares at a formula price even if the offeror does not initiate a freezeout transaction. All three categories of amendment will usually share a further provision-the requirement of a supermajority shareholder vote for further amendment or repeal. This Part first describes the principal features of each category of amendment, and then considers the persuasiveness of claims for their effectiveness.

\section{A. The Three Categories of Shark Repellent Amendments}

\section{Impeding transfer of control of the board of directors.}

Under a typical corporation statute, an offeror, having successfully tendered for a majority of a target's shares, will encounter little delay in replacing the target's board of directors. Most corporations elect their board of directors annually, ${ }^{18}$ without cumulative voting. ${ }^{19}$ A new majority shareholder who is unwilling to wait until the next annual meeting of shareholders to install his designees may re-

18. E.g., CAL. Corp. Code $\S 301$ (a) (West 1977); ABA-ALI MOdel Bus. Corp. ACT ANN. 2D $\$ 36$ (1971 \& Supp. 1977).

19. A few states, such as California, CaL. CoRP. Code $\S 708$ (West Supp. 1981), Illinois, ILl. ANN. STAT. ch. 32, § 157.28 (Smith-Hurd Supp. 1981), and North Carolina, N.C. GeN. STAT. $\$ \S 55-67$ (1975), provide for mandatory cumulative voting. Other states allow cumulative voting if the articles of incorporation so provide. E.g., DEL. CODE ANN. tit. 8, § 214 (1975); N.Y. Bus. CORP. LAW § 618 (McKinney 1963). 
move the incumbent directors without cause ${ }^{20}$ and select their replacements, ${ }^{21}$ either by written consent ${ }^{22}$ or at a special shareholders' meeting called pursuant to the majority holder's request. ${ }^{23}$

Shark repellent amendments in theory can delay this process substantially. The initial step is to classify the board into, for example, three classes of which only one is elected annually. ${ }^{24}$ The effect, of course, is to require up to two annual meetings for a successful offeror to select a majority of the board through the normal election process. $^{25}$

But classification alone will not prevent a majority shareholder from removing and replacing incumbent directors or, if the particular state statute bars removal of directors without cause or bars such removal where the board is classified, ${ }^{26}$ from "packing" the board of directors by amending the charter or bylaws ${ }^{27}$ so that directors elected by the offeror to fill new vacancies will constitute a majority. Therefore, a complete set of amendments to protect the tenure and majority of pre-offer board members must go beyond classification and reserve to the board the sole right to determine the number of directors and to fill any vacancies created by resignation or increase

20. See, e.g., Cal. CoRp. Code $\S 303$ (West 1977); Del. Code AnN. tit. 8, § $141(\mathrm{k})$ (Supp. 1980); ABA-ALI MODEL BUS. CORP. ACT ANN. 2D $\$ 39$ (1971).

21. See, e.g., Gal. CoRp. CODE § 305(a) (West Supp. 1981); Del. Code ANN. tit. 8, $\S 223$ (1975).

22. See, e.g., Gal. Corp. Code $\S 305$ (b) (West Supp. 1981); Del. Code AnN. tit. 8, $\S 211(\mathrm{e})(1975)$.

23. See, e.g. , CAL. CORP. CODE $\S 305$ (c) (West Supp. 1981) (meeting called by holders of an aggregate of $5 \%$ or more of outstanding shares having right to vote); DEL. CODE ANN. tit. $8, \S 223$ (c) (1975) (meeting called by holders of at least $10 \%$ of outstanding shares having right to vote).

24. While the corporate laws of some states allow creation of more than three classes, e.g., FLA. STAT. ANN. §607.114(4) (West 1977) (not more than four); N.Y. Bus. CoRP. LAW \$ 704(a) (McKinney 1963) (two, three, or four), both Delaware, DeL. CODE ANN. tit. 8, \$ 141 (d) (Supp. 1980), and the New York Stock Exchange, New York Stock Exchange Company Manual § A-15, at A-280 (Aug. 1, 1977), limit the number of classes to three.

25. The time necessary will be between two and three years depending on how soon after an annual meeting the new majority shareholder acquired that status. Hochman \& Folger, supra note 6 , note that, by combining classification of the board with cumulative voting, "even a dissident shareholder who controls 70 per cent of the votes cast might, after two successive annual meetings, find that he had been able to elect only four of the nine directors." Id. at 539.

26. E.g., Del. Code ANN. tit. 8, § 141(k)(1) (Supp. 1980).

27. E.g., id. $\S 141$ (b) (number of directors fixed by the bylaws, "unless the certificate of incorporation fixes the number of directors, in which case a change in the number of directors shall be made only by amendment of the certificate'); ABA-ALI MODEL BUS. CORP. ACT ANN. 2D § 36 (1971). 
in the number of directors. ${ }^{28}$ Amendments may also limit the mechanics of "flanking" action-the call of special meetings of shareholders and shareholders' ability to act by written consent ${ }^{29}$-as well as restrict removal of directors to instances of "cause" narrowly defined. ${ }^{30}$

Even a full complement of these amendments, however, can only delay the transfer of control. If the offeror is content to wait the period necessary to secure control of the target's board of directors, the protective amendments will achieve little, save for distinguishing the target from other corporations that may not have adopted similar measures. $^{31}$ However, delay in the shift in control of the target's board of directors may be a significant deterrent to making an offer.

The deterrent effect of delay can be seen through examination of the factors that motivated the transaction in the first place. For example, if the motive for the merger was to achieve synergy through cost reductions (from sharing product distribution systems or eliminating duplicative costs and facilities), ${ }^{32}$ then delay puts off the time when the anticipated benefits can be realized. If the motive for the acquisition was to displace inefficient management, delay not only

28. See, c.g., Proxy Statement of PSA, Inc. (Oct. 23, 1978), reprinted in A. Fleischer, supra note 2, at 400-1. For convenience I provide, where possible, references to proxy statements that have been reprinted in an accessible source.

29. E.g., id. at 400-9 to -10; Proxy Statement of Executive Industries, Inc. (May 30, 1979), reprinted in 2 M. LIPTON \& E. STEINBERGER, supra note 1, at L-3.

30. Proxy Statement of Alberto-Culver (Dec. 15, 1978), reprinted in A. FleISCHER, supra note 2, at 400-99, 400-106 (extract) (cause limited to conviction for a felony or "an adjudication of a court of competent jurisdiction of negligence. . . in the performance of duty to the Company in a matter of substantial importance to the Company.").

31. See notes 100-09 infra and accompanying text.

32. The term synergy refers to the phenomenon occurring when the value of the combined entity exceeds the sum of the precombination values of the acquiring and target companies. See, e.g., M. Salter \& W. Weinhold, Diversification Through Acquisition: Strategies for Creating Economic Value 9 (1979); J. Van Horne, Financlal ManAGEMENT AND POLICY 243-48 (5th ed. 1980). Two explanations for synergy are commonly offered. The first, an operational approach, focuses on the potential for cost reductions in the combination of complementary businesses. See, e.g., P. Steiner, Mergers: Motives, EFFECTS, POLICIES 47-74 (1975); Alberts, The Profilability of Growth by Merger, in THE CoRPORATE MERger 235, 247-62 (W. Alberts \& J. Segall eds. 1966). The second, a financial approach, focuses on such matters as the opportunity for transfer of working capital between divisions in preference to outside financing and an increase in the debt capacity of the firm. See, e.g. , Lewellen, A Pure Financial Rationale for the Conglomerate Merger, 26 J. FIN. 521 (1971); see also O. Williamson, CoRPorate Control AND Business BeHavior 109-66 (1970); Scott, On the Theory of Conglomerate Mergers, 32 J. Fin. 1235 (1977). The growth of the enterprise resulting from even synergistic acquisitions imposes organizational costs that offset these benefits. O. Williamson, Markets AND Hierarchies: ANAlysis AND ANTITRust IMPLigaTIONS 117-31 (1975). 
postpones the expected return on the offeror's investment, but also raises the potential that at least some of the losses suffered due to incumbent management's inefficiency during the postoffer, precontrol period may prove irreversible: The loss may be of a character that better management cannot recapture at a later date. ${ }^{33}$ Finally, if the target's funds or cash flow was expected to repay high-interest loans financing the acquisition, delay in being able to exercise control may increase the cost of the acquisition.

\section{Barriers to second-step transactions.}

Often a tender offer represents only the first step in a plan for the complete acquisition of the target. The second step is commonly a merger in which any remaining minority shareholders are frozen out of the new subsidiary. ${ }^{34}$ The second group of shark repellent amendments is intended to make this second-step transaction more difficult.

All corporate statutes require that shareholders approve a statutory merger, ${ }^{35}$ and most allow the articles of incorporation to impose a greater-than-majority vote requirement with respect to particular transactions. ${ }^{36}$ The typical defensive amendment package can therefore impose a barrier to second-step transactions through a supermajority shareholder vote requirement-generally from twothirds to as high as $95 \%{ }^{37}$ - for a freezeout merger or comparable transaction ${ }^{38}$ with a "related person"39 —an intricately defined term

33. See Smiley, Tender Offers, Transactions Costs and the Theory of the Fim, 58 REv. ECON. \& Statistias 22, 30 (1976).

34. See, e.g., Brudney \& Chirelstein, A Restatement of Corporate Freezeouts, 87 YALE L.J. 1354 (1978); Greene, Corporate Freeze-out Mergers: A Proposed Analysis, 28 STAN. L. REV. 487 (1976). Where both steps are intended from the outset, and particularly where the secondstep transaction offers the minority shareholder only cash, the effect of the entire transaction is equivalent to a one-step merger in which dissenters have only the alternative of cash appraisal rights.

35. E.g. , Cal. Corp. Code $\S 1201$ (West Supp. 1981); Del. Code ANN. tit. 8, § 251 (1975 \& Supp. 1980); N.Y. Bus. CoRP. LAW $\S 903$ (McKinney Supp. 1980); ABA-ALI MOdel Bus. CoRP. ACT. ANN. 2d § 73 (Supp. 1977).

36. See note 116 infra and accompanying text.

37. See, e.g., Proxy Statement of Universal Leaf Tobacco Co. (Jan. 21, 1977), reprinted in 2 M. Lipton \& E. STEINBERGER, supra note 1, at L-1 (proposing 80\% requirement); Proxy Statement of Rubbermaid, Inc. (Mar. 24, 1978), reprinted in 2 M. LIPTON \& E. STEINBERGER, supra note 1, at L-2 (proposing 85\% requirement); Proxy Statement of Chicago Pneumatic Tool Co. (Apr. 18, 1975), reprinted in A. FleISCHER, supra note 2, at 439, 440 (extract) (proposing $95 \%$ requirement).

38. Because the form of transaction by which a minority can be frozen out is limited only by the planner's imagination, the definition must be broad enough to prevent formal circumvention. A typical definition is contained in the amendments adopted by PSA, Inc.: 
which will always include a successful tender offeror. The percentage required for approval is often chosen to approximate the average number of shares represented at the past few annual meetings, ${ }^{40}$ in effect requiring an offeror to procure a virtually unanimous vote. Since the combined shareholdings of incumbent directors, officers, and their affiliates often approach or exceed the number of shares necessary to block the requisite supermajority, ${ }^{41}$ these provisions may

The term "business combination" shall mean (a) any merger or consolidation of this corporation with or into a related person, (b) any sale, lease, exchange, transfer or other disposition, including without limitation, a mortgage or any other security device, of all or any substantial part of the assets of this corporation (including without limitation any voting securities of a subsidiary) or of a subsidiary, to a related person, (c) any merger or consolidation of a related person with or into this corporation or a subsidiary of this corporation, (d) any sale, lease, exchange, transfer or other disposition of all or any substantial part of the assets of a related person to this corporation or a subsidiary of this corporation, (e) the issuance of any securities of this corporation or a subsidiary of this corporation to a related person, $(f)$ the acquisition by this corporation or a subsidiary of this corporation of any securities of a related person, (g) any reclassification of Common Stock of this corporation, or any recapitalization involving Common Stock of this corporation, consummated within five years after a related person becomes a related person, and (h) any agreement, contract or other arrangement providing for any of the transactions described in this definition of business combination.

Proxy Statement of PSA, Inc., supra note 28, at 400-18.

39. A "related person" is defined in id. at 400-18 to -19.

40. See, e.g., Proxy Statement of J.M. Smucker Co. (July 25, 1977), reprinted in A. FLEISCHER, supra note 2, at 425, 427 (extract) (supermajority requirement represents "the average percentage of shares represented at the last five annual meetings").

41. See, e.g., Proxy Statement of Baldor Electric Co. (Mar. 30, 1979), reprinted in A. FLEISCHER, supra note 2, at 400-21 to -25 (proposing $80 \%$ requirement; officers and directors as a group owned 37.6\%); Proxy Statement of Farm House Foods Corp. 3 (Sept. 8, 1980) ("The anti-takeover provisions will also enable the present principal shareholders [management] of the Company, if they act as a group, to veto any proposed merger, tender offer or other attempt to gain control of the Company.'); Proxy Statement of Thomas Indus., Inc. 6 (Mar. 24, 1980) ("If the proposed amendment is adopted, the Board of Directors believes that under present circumstances it could prevent any proposed merger or similar transaction which, in its judgment, should be rejected.")

Management may increase the percentage required for approval by requiring that, in addition to meeting the overall supermajority figure, the transaction also be approved by a majority of the shareholders unrelated to the offeror. E.g., Proxy Statement of Baldor Electric Co., supra, at $400-25$. The result is to increase the overall percentage required for approval as the number of shares acquired in the initial tender offer increases. Thus, if the supermajority requirement were $662 / 3 \%$, an offeror securing that amount would be subject to an actual supermajority requirement of $84 \%$ (67\% acquired in the initial tender plus the $17 \%$ majority of the $33 \%$ not acquired in the tender). If the offeror had acquired $80 \%$ in the initial tender, the supermajority vote required would be $91 \%$ ( $80 \%$ plus the $11 \%$ majority of the $20 \%$ not acquired in the tender).

When the strategic response of the offeror to such a provision is considered, the outcome is ironic. Since the overall percentage approval required increases with the number of shares acquired in the initial offer, the offeror has an incentive to acquire fewer shares at that stage. For example, if the offeror believed $80 \%$ of the target's shares would be tendered, and if there was a supermajority requirement of $662 / 3 \%$ plus a majority of the minority shares, the initial 
present a significant barrier to a second-step transaction by a successful tender offeror. ${ }^{42}$

Anti-freezeout amendments, however, usually do not impede all transactions falling within their complex definitions. Having broadly defined the covered "transactions" in order to avoid circumvention, the amendments usually include exceptions to the supermajority requirement to permit transactions favored by management, such as a friendly takeover or other transaction not motivated by an impending tender offer. ${ }^{43}$ These exceptions allow transactions that are approved by a supermajority of "continuing" directorsthose who were in office at the time the related party initially acquired any substantial interest in the corporation. ${ }^{44}$ The purpose of that formulation, of course, is to prevent recourse to the exception by a board of directors "packed" or otherwise controlled by the "related person."

tender might then be for $51 \%$, rather than for all of the outstanding shares. If $51 \%$ were acquired in the initial tender, the supermajority vote required for a second-step transaction would be $662 / 3 \%$, of which $51 \%$ would be supplied by the offeror's shares and $16 \%$ by the holders of the $29 \%$ who would have tendered and, presumably, would favor a second-step transaction. A majority of nonofferor shares would require a $25 \%$ vote which also would be supplied by the $29 \%$ who would have tendered. By comparison, a second-step transaction following the acquisition of $60 \%$ in the initial offer would require a vote of $21 \%$ of the shareholders to satisfy the independent majority requirement, but only $20 \%$ of the shares originally held by those who would have tendered would remain unpurchased.

In short, the effect of a provision designed to protect minority shareholders from the risk of a freezeout may have the effect of increasing the number of shareholders subject to that risk.

42. This point is considered in notes 78-96 infra and accompanying text.

43. E.g. A. FLEISGHER, supra note 2, at 21; Hochman \& Folger, supra note 6, at 550-52.

44. For example, the Proxy Statement of Thomas Industries, Inc., supra note 41, at 18, excludes from the supermajority requirement a transaction which is:

approved by the Board of Directors of this corporation, provided that a majority of the members of the Board of Directors voting for the approval of such transaction were duly elected and acting members of the Board of Directors prior to the time that such other corporation, person or other entity shall have become a beneficial owner of more than 5\% in number of the outstanding shares of stock of any class of this corporation entitled to vote in elections of directors.

Also commonly excluded from the application of the supermajority requirement are internal corporate transactions, typically covering "business combinations" involving subsidiaries of the corporation. See, e.g., Proxy Statement of PSA, Inc., supra note 28, at 400-8 to -9. The pitfalls of drafting these provisions are demonstrated by Young v. Valhi, Inc., 382 A.2d 1372 (Del. Ch. 1978), where a creative offeror sought, albeit unsuccessfully, to avoid an $80 \%$ supermajority requirement by merging the target into a wholly owned subsidiary of the target and using that merger, exempted from the $80 \%$ requirement by an internal transaction exception, to freeze out the minority.

45. A common variant of the exception for approval by the target's board of directors further constrains the postacquisition board by limiting the exception to approval secured before the acquirer became a "related person." See, e.g., Proxy Statement of Baldor Electric 
For a variety of reasons, the ability to effect the second-step transaction may be quite important to the offeror. First, eliminating minority shareholders may be crucial to securing synergistic benefits from combining the two businesses. Merging administrative and support systems with the intent of reducing total costs by, for example, central financing, insurance purchasing, or participation in parent self-insurance programs, may pose serious problems of allocating cost, profit, and participation where the subsidiary has minority shareholders. ${ }^{46}$ Second, when too many minority shareholders remain, there may be nontrivial costs associated with maintaining shareholder records and stock transfer facilities and continuing to make the disclosures required by federal and state corporate and securities laws. ${ }^{47}$ Finally, if displacement of inefficient management, or the offeror's foresight in recognizing the target's "intrinsic" value, results in an increase in the value of the target following the tender offer, the elimination of minority shareholders allows the offeror to obtain that portion of the increase that might otherwise go to the minority. ${ }^{48}$ The second group of shark repellent amendments, therefore, seeks to deter by denying the offeror the benefits of the secondstep transaction.

\section{Fair price and compulsory redemption provisions.}

Fair price amendments are a variation on the supermajority theme. They provide another exception to a supermajority vote re-

Co., supra note 41 , at $400-38$. The effect of such a provision where there is no other exception is to eliminate any discretion in the postoffer board, however composed, to waive the supermajority requirement. In this respect the provision operates, in effect, as a "doomsday machine."

46. See, e.g., M. Eisenberg, The Structure of THe Corporation 308-09 (1976); Borden, Going Privale-Old Tort, New Tort, or No Tort?, 49 N.Y.U. L. REv. 987,1018 (1974).

47. Issuers subject to reporting under $\$ 13$ of the Securities Exchange Act of 1934, 15 U.S.C. $\$ 78 \mathrm{~m}$ (1976), are required to file, inter alia, a Form 10-K Annual Report, Form 10-Q Quarterly Reports, and Form 8-K Current Reports. These reporting obligations are surveyed in Securities Act Release No. 6231, Securities Exchange Act Release No. 17,114, Integration of Securities Acts Disclosure Systems, reprinled in 6 FED. SEC. L. REP. (CCH) I 72,301 (Sept. 2, 1980). A corporation may free itself from these obligations if the number of its shareholders drops below 300 , either through deregistration pursuant to $\$ 12(\mathrm{~g})(4), 15$ U.S.C. $\S 78 /(\mathrm{g})(4)$ (1976), if the reporting obligation arose pursuant to $\S 12$, or pursuant to $\S 15$ (d), id. $\S 780$ (d), if it arose by undertaking. There are also reporting requirements imposed by some state corporation laws. E.g., CAL. CoRP. CoDE $\S 1501$ (West Supp. 1981) (mailing of annual report containing balance sheet and income statement and, for corporations with more than 100 shareholders, information concerning transactions with directors and officers); N.Y. Bus. CORP. LAW \$ 624(e) (MCKinney 1963) (mailing of balance sheet and income statement to shareholders upon written request).

48. But see note 94 infra. 
quirement for a second-step transaction where the price to be paid minority shareholders exceeds a specified amount which may be greater than the price paid in the initial tender offer. ${ }^{49}$

In an important sense, fair price provisions are inconsistent with the approach reflected in the standard supermajority provision. Rather than strengthening the barriers to second-step transactions, a fair price exception instead provides a way to effect the second-step transaction, albeit at a share price that may be higher than that paid in the initial tender offer. ${ }^{50}$ Further, it can be said that a fair price provision, rather than reflecting management self-interest, recognizes the potential danger to minority shareholders in second-step transactions by tying the application of the supermajority requirement to "fairness" to minority shareholders.

The position of minority shareholders following a tender offer is also emphasized in right of redemption provisions, the newest ${ }^{51}$ and, so far, least popular variety of shark repellent amendment. This

49. A typical formulation waives the supermajority requirement if the price to be paid is equal to or greater than the highest of: (1) the highest price paid by the offeror for any shares acquired during the offer; (2) a price which reflects the same percentage premium (based on the price of the target's stock at the time the second-step transaction was announced) as the initial offer (based on the price of the target stock at the commencement of the initial offer); and (3) an amount determined by multiplying the target's average earnings per share over the previous four years by the offeror's price-earnings ratio over that time. All three alternatives are reflected in the Proxy Statement of Chicago Pneumatic Tool Co., supra note 37 , at 441 .

While the point of the first two price measures is apparent, the theory behind the thirdtarget earnings multiplied by offeror's price-earnings ratio-is somewhat obscure. During the heyday of the conglomerates in the 1960s it was thought that the acquisition of a company with a low price-earnings ratio by a glamour company with a high price-earnings ratio could achieve corporate alchemy: The same earnings, from the same business, would support a higher share price within one corporation than they would within another. If, for example, the target had earnings of $\$ 2$ per share, a price-earnings ratio of 5 , and a share price of $\$ 10$, and the offeror had a price-earnings ratio of 20 , the argument was that the acquisition of the target's earnings would boost the share value of the offeror to \$40. See, e.g., A. BRILOFF, UNACCOUNTABLE ACCOUNTING 59-87 (1972); J. BROOKS, THE GO-Go YeARS 156-58 (1973); P. STEINER, supra note 32, at 103-09. The third element of the price formula attempts to capture this increase for the minority shareholder. Consistent with the efficient capital market hypothesis, empirical evidence suggests that this form of financial synergy does not exist. See id. at 109-27; Hong, Kaplan \& Mandelker, Pooling os. Purchase: The Effects of Accounting for Mergers on Slock Prices, 53 ACCT. REv. 31 (1978).

50. It has been suggested that a premium be added to the fair price determined under the formula-for example, 50\% "of the highest consolidated balance of domestic and foreign cash, cash equivalents and marketable securities" held by the target during a specified period-as an asset bonus. Smith, supra note 6, at 17. Additionally, the formula itself is capable of yielding a price in excess of the initial tender price.

51. This form of provision was apparently first used by Rubbermaid. See Proxy Statement of Rubbermaid, Inc., supra note 37 , at $400-46$ to -47 . 
amendment, seemingly borrowed in concept from section 209(2) of the English Companies Act, ${ }^{52}$ allows any minority shareholder, following a successful offer for more than a specified percentage of the target's outstanding shares, to require the target company to purchase the remaining shares at a formula price that equals or may even exceed the price paid in the tender offer. ${ }^{53}$

52. $11 \& 12$ Geo. 6, ch. 38, § 209(2) (1948). Since 1929 the Companies Act has contained a provision, now $\S 209(1)$, which allows an offeror securing $90 \%$ of a target's stock to require that the remaining $10 \%$ be sold to it at the tender offer price. In 1948, $\S 209(2)$ was added to give minority shareholders a complementary remedy. This section gives the remaining shareholders in a target, following the acquisition by an offeror of in excess of $90 \%$ of the target's outstanding shares, the right to require the offeror to purchase their shares either at the tender price or at a court-determined price. See 1 C. SCHMITTHOFF, PALMER's CoMPanY LAW 865-71 (22d ed. 1976) [hereinafter cited as PALMER's COMPANY LAW]; M. WEINBERG, TAKE-OVERS AND MERgERS 189-91, 207-11 (3d ed. 1971). The concern evidenced in $\S 209(2)$ for the plight of a minority shareholder who is not frozen out is further expressed in General Principle 13 of the London City Code on Takeovers and Mergers, PANEL ON TAKEOvers \& Mergers, The Gity Code on TAKe-Overs AND Mergers (rev. ed. 1976), reprinted in 3 PALMER's COMPANY LAW, supra, at 4505, 4513, which requires "a general offer to all other shareholders" when control shifts. This principle is given specific form in Rule 34 of the City Code. See A. Johnson, The Gity Take-Over Code 267-81 (1980).

It is interesting that the focus of regulatory concern in the United Kingdom is on the shareholder who is not frozen out following a tender offer, while that in the United States is on the shareholder who is frozen out. Compare Companies Act $\S 209(2), 11$ \& 12 Geo. 6, ch. 38, $\S 209$ (2) (1948), with Roland Int'l Corp. v. Najjar, 407 A.2d 1032 (Del. 1979); Singer v. Magnavox Co., 380 A.2d 969 (Del. 1977); Tanzer v. International Gen. Indus., Inc., 379 A.2d 1121 (Del. 1977); and Brudney \& Chirelstein, supra note 34. But of. Jones v. H.F. Ahmanson \& Co., 1 Cal. 3d 93, 460 P.2d 464, 81 Cal. Rptr. 592 (1969) (judicial concern for minority shareholders denied access to a public market for their stock). It is hard to avoid the suspicion that American law has made the wrong choice. On the one hand, it is difficult to identify the additional criteria by which the "entire fairness" of a freezeout merger, whose price is fair on an appraisal basis and which serves a corporate purpose, is to be judged. See Weinberger v. UOP, Inc., 426 A.2d 1333 (Del. Ch. 1981). Certainly focus on whether the minority shareholders approved the freezeout, which seems to be a major focus in recent case law, see, e.g., id.; Gelfond \& Sebastian, Reevaluating the Duties of Target Management in a Hostile Tender Offer, 60 B.U.L. REv. 403, 448 n.307 (1980), adds nothing in light of the obvious intent of the statutory authorization of the short form merger technique to eliminate this form of holdout. But of. Lynch v. Vickers Energy Corp., 429 A.2d 497, 501 (Del. 1981) (rejecting appraisal standard as measure of damages for breach of fiduciary duty in freezeout context because appraisal does not reflect the "gain to the corporation resulting from a statutory merger"). On the other hand, the body of fiduciary doctrine protecting the minority shareholder in a subsidiary is unsatisfactory at best. The explanation for the American choice may be no more complicated than that the Singer line of cases arose at a time when Delaware corporate law was under critical attack, see Cary, Federalism and Corporate Law: Refections Upon Delaware, 83 YALE L.J. $663,679-83$ (1974), and the fiduciary duty doctrine, always a judicial rather than a legislative construct in Delaware, see Gilson, supra note 2, at 832-33, presented the courts an opportunity to respond. See Brudney \& Chirelstein, supra note 34, at 1354 n.2 (suggesting relationship between Cary article and Singer decision).

53. The Rubbermaid formula specifies the redemption price as the highest of: (1) the per share book value, (2) the highest price paid by the offeror within the previous 18 months, and (3) the highest price at which the target stock traded within the previous 18 months. 
While a right of redemption provision focuses on the position of the minority shareholder who does not tender, it may be a more substantial deterrent to an offeror than a fair price provision in certain circumstances. If a potential offeror contemplates an offer for less than $100 \%$ of a target's stock, a right of redemption provision may remove control over the size of an offeror's total investment from its hands. Because shareholders may in effect force a second-step transaction by exercising their right to require redemption, they, and not the offeror, have the last word on the number of shares ultimately acquired and, if the provision's pricing formula could yield a price higher than the offer, on the price to be paid. Indeed, a fair price provision may even deter an offeror who is willing and financially able to tender for all the outstanding shares. If the pricing formula assures holdouts a price no lower than the tender offer and provides the potential of a higher price, target shareholders will be given an incentive not to tender in the original offer. ${ }^{54}$

Proxy Statement of Rubbermaid, Inc., supra note 37, at 400-46. It has not been uncommon in recent years for a tender offer price to be below book value, see, e.g. , Singer v. Magnavox, 380 A.2d 969, 971 (Del. 1977), or for the offer to be made at a price below the 18-month high. To that extent, the redemption price could be in excess of the tender price. Moreover, the more expansive formulas recommended for use in fair price provisions, see notes $49-50$ supra, could be extended to right of redemption provisions.

54. This phenomenon is described with respect to a fair price provision in Hochman \& Folger, supra note 6 , at 555 :

Chicago Pneumatic Corporation recently had occasion to make use of its fair price provision after learning that 5 per cent or more of its shares had been purchased by another company. It announced to brokers that, under its fair price provision, shareholders who chose not to sell to a raider might profit handsomely from a higher price if a raider gains control and then attempts to squeeze out remaining shareholders. According to Robert Metz of the New York Times, "the announcement-calculated to guarantee full disclosure to existing stockholdersevidently had the desired effect. Brokers from all over the nation called Chicago Pneumatic's headquarters in New York City and asked for copies of the charter."

(quoting Metz, Brokers Heed Stock Waming, N.Y. Times, May 30, 1978, at D-5, col. 1). The effect might be even more pronounced in a right of redemption context since the offeror would no longer have the option not to squeeze out the minority. The deterrent created by right of redemption provisions is discussed in notes 97-99 infra and accompanying text.

Although not shark repellent amendments in that they are not intended to pose a deterrent to an offeror, social justice amendments, pioneered by Control Data, see Proxy Statement of Control Data Corp., reprinted in A. FleIScHER, supra note 2, at 448-11 (extract), and more recently adopted by McDonald's, see Proxy Statement of McDonald's Corp., reprinted in A. FLEISCHER, supra note 2, at 448-13 (extract), warrant comment. These amendments, purportedly offered "in the spirit of social responsibility and justice," Proxy Statement of Control Data Corp., supra, at 448-11, direct the board of directors, in their evaluation of an acquisition offer, to "give due consideration to all relevant factors, including without limitation the social and economic effects on the employees, customers, suppliers and other constituents of 


\section{B. Lock-up Amendments}

While not themselves shark repellents, lock-up amendments are probably the most important and in some respects the most troubling of the amendments a potential target commonly adopts to deter unwanted tender offers. Consider a potential offeror's evaluation of a target draped with the full panoply of protective amendments. While a $95 \%$ vote may be required for a second-step transaction, unless the target's charter also has been amended to require a supermajority to further amend the charter itself, a successful offeror can eliminate the supermajority provision by the vote for charter amendment specified in the statute-typically a simple majority. ${ }^{55}$ The carefully plotted defensive measures would then be left, like the Maginot Line, with their guns pointing in the wrong direction. To avoid this result, virtually all shark repellent amendments also require a supermajority vote for repeal or further amendment.

Lock-up amendments are thus the key to whatever potential for deterrence any of the shark repellent amendments may possess. Moreover, they highlight the central challenge shark repellents present to traditional conceptions of corporate democracy. ${ }^{56}$ The problem, of course, is that a $51 \%$ majority can adopt an amendment requiring a $95 \%$ majority later to amend it; one majority can thereby bind a future majority. Put differently, a present majority can reduce the value of a future majority's votes.

While this result has evoked strident criticism from some commentators, the criticism has been formulated, by and large, in ideological rather than analytical terms. We are told that such provisions

the Corporation and its subsidiaries and on the communities in which the Corporation and its subsidiaries operate or are located," id. at 448-12.

Social justice amendments do not provide a deterrent to a potential offeror, but rather attempt to protect management from subsequent shareholder claims based on management's rejection of an offer. Indeed, the McDonald's Corporation proxy statement proposing such an amendment was explicit in stating that the provision was not intended "to create any rights on behalf of franchisees, employees, suppliers, customers or any other persons." Proxy Statement of McDonald's Corp., supra, at 448-13. While an offeror might conceivably be deterred by the potential increase in discretion the board of directors may gain from a social justice provision, the likelihood of deterrence seems remote at best.

One might argue, however, that the adoption of the amendment serves as a signal that management intends to oppose vigorously any offers which might be made. See notes 100-09 infra and accompanying text.

55. E.g., Del. Code ANN. tit. 8, § 242(c)(1) (Supp. 1980); N.Y. Bus. Corp. LAw $\S 803$ (a) (McKinney Supp. 1980-1981); ABA-ALI MODEL Bus. CoRP. Act ANN. 2D § 59 (1971).

56. Because of this they received critical attention by commentators more than 10 years ago. See Cary, supra note 7; Wetzel, supra note 7. 
"are contrary to the basic principles of corporate democracy" and that they "transform the will of the majority into what may be described as the tyranny of the minority, "158 but we are not told in any precise terms what is wrong.

The absence of analytical clarity is not surprising. The issue framed by a lock-up amendment may be viewed as the extent to which the influence of a majority shareholder may be diluted without that shareholder's consent. Where that dilution occurs when the identity of that majority shareholder is known, there is at least some precedent that touches on the problem. In Condec v. Lunkenkeimer, ${ }^{59}$ an offeror had acquired a majority of the target's outstanding shares. But before the offeror had the opportunity to pursue its advantage, target management entered into a transaction with another suitor-a "white knight" in today's terms-issuing the friendly suitor enough target shares to reduce the offeror's holdings below 51\%. ${ }^{60}$ Focusing on the right of a majority holder to the benefits of its position, the court disallowed the transaction as "clearly unwarranted because it unjustifiably strikes at the very heart of corporate representation by causing a stockholder with an equitable right to a majority of corporate stock to have his right to a proportionate voice and influence in corporate affairs to be diminished." 61

The problem becomes more difficult, however, when the majority whose "right to a proportionate voice and influence" is diminished will come into being only at some time in the future. In other words, the nature of the conflict is shifted from the ability of a present minority to limit a present majority, to the right of a present majority to allow a future minority to so limit a future majority.

That the future majority is only an expectancy-the point, after all, of an argument which responds to a complaint that it is unfair for today's $51 \%$ to bind tomorrow's $69 \%$ by claiming that "the time for the $69 \%$ stockholders to be heard is when the vote is taken on the supermajority provisions"62 even though those shareholders do not yet exist—ought not in itself to resolve the issue. As John Rawls has stated in a broader context:

The mere difference of location in time, of something's being earlier or later, is not in itself a rational ground for having more or less

57. E. ARANOW, H. EINHORN \& G. BERLSTEIN, supra note 6 , at 195.

58. Id.

59. 230 A.2d 769 (Del. Ch. 1967).

60. Id. at 772 .

61. Id. at 777 .

62. Hochman \& Folger, supra note 6, at 546. 
regard for it. . . . [I]n first principles of justice we are not allowed to treat generations differently solely on the grounds that they are earlier or later in time. ${ }^{63}$

In other words, one must determine why it is desirable to favor the present majority. A lock-up amendment does no more than to state the favoritism and itself serves no independent purpose; it functions only to facilitate the operation of the substantive provisions whose existence it protects. Given that, the justification and validity of lock-up amendments should be derivative-depending on that of the underlying provisions. ${ }^{64}$ If we are to allow a bias in favor of the present majority, it must rest on a careful consideration of the structure of the corporate entity whose rules that majority seeks to alter. ${ }^{65}$

\section{Efficacy of the Deterrent}

Despite the logic underlying the expectation that shark repellent amendments will deter potential offerors, and despite the chorus of voices urging their adoption, ${ }^{66}$ some prominent practitioners have asserted that such provisions do not fulfill their promise. ${ }^{67}$ An exami-

63. J. RAwLS, A TheORY OF Justice 293, 295 (1971) (emphasis added).

64. The derivative character of lock-up amendments turns out to be of substantial value in identifying those shark repellent amendments which are invalid. See notes 207-19 infra and accompanying text.

65. From one perspective, the dilution of the future majority's position poses no question of unfairness. If that dilution is perceived as unfavorable, it will reduce the value of the company's shares to a future purchaser. The future purchaser then pays a price that reflects the dilution, and the cost - a reduction in the value of the company's shares-is borne by the present shareholders. See R. POSNER, ECONOMIC ANALySis OF LAW 302 (2d ed. 1977); Jensen \& Meckling, Theory of the Firm: Managerial Behavior, Agengy Costs and Ownership Structure, $3 \mathrm{~J}$. Fin. ECON. 305, 312-13 (1976). Thus, present shareholders bear the cost of their actions and future shareholders get precisely what they pay for.

While reassuring, the argument is not persuasive. Most important, it ignores the fact of managerial control in modern public corporations: While the shareholders bear the cost of defensive tactics, management reaps the benefits. See Gilson, supra note 2, at 846 . Viewed in this way, the unfairness is an imposed wealth transfer from present shareholders to management. To be sure, present shareholders-at least with respect to shark repellent amendments-will have voted in favor of this result. But whether a shareholder vote eliminates the unfairness depends on how much reliance can be placed on the proxy system as a means of reflecting actual shareholder preference, a subject considered in the text accompanying notes 193-206 infra. Moreover, even if a shareholder vote were thought to reflect shareholder preferences accurately, the increase in managerial discretion to diverge from profit maximization due to reduced potential for a tender offer, see Easterbrook \& Fischel, supra note 13, at 1174-76; Gilson supra note 2, at 845-46, represents a threat to societal interests in the efficient allocation of resources. See Grossman \& Hart, Takeover Bids, the free-rider problem, and the theory of the corporation, 11 BeLL J. ECON. 42, 54-57 (1980).

66. See note 6 supra.

67. Indeed, Joseph Flom has characterized the approach as a "total waste of time." Transcript, Tenth ANNUAl Institute on Securities Regulation 443 (1978), quoted in A. 
nation of the three categories of amendments I have considered suggests that there is substantial basis for questioning the extent of their deterrence. While there are circumstances where shark repellent amendments will have some effect, it seems clear that their potential for deterrence has been substantially exaggerated. ${ }^{68}$

\section{Impeding transfer of control of the board of directors.}

The deterrent effect of an incumbency amendment is premised on the belief that immediate control of the target's board of directors is so important to the offeror that the prospect of substantial delay in achieving it will make a particular acquisition less attractive. ${ }^{69}$ Still, the extent of any deterrence ultimately depends on how effective the delaying mechanism is. Amendments seeking to delay transfer of board control necessarily assume that the incumbent directors will choose to remain in office and exercise the authority given them by the shark repellent amendments to control board size and name successor directors in a manner inconsistent with the desires of the successful offeror. This central assumption about the behavior of incumbent directors is open to serious question. It depends, in the final analysis, on the potential offeror believing that even after the offer is successful, members of the incumbent board will act in a fashion inconsistent with their own self-interest.

Consider the position of a target company's incumbent directors following a successful tender offer. A new majority shareholder now exists who wishes to control the target's board. The incumbent board will consist of some combination of owner-managers, ${ }^{70}$ professional managers, ${ }^{71}$ and, increasingly, independent directors. ${ }^{72}$ Analy-

FleISCHER, supra note 2, at $7 \mathrm{n} .23$. And Martin Lipton has concluded that shark repellent amendments' "efficacy is open to debate." 1 M. LIPTON \& E. STEINBERGER, supra note 1, at 265-66; see also A. FlEISCHER, supra note 2, at 6-8; E. ARANOW \& H. EINHORN, supra note 6, at 259. Flom and Lipton are the best known of the tender offer practitioners. See Flom Firm Takes Over as Top Money Maker in '78, Am. Law., Feb. 1979, at 1, col. 1; Gurwin, supra note 2, at 34 ("everyone wants one or the other [Flom or Lipton] on his side").

68. For an example of a more or less effective shark repellent amendment, see note 85 infra and accompanying text.

69. See note 33 supra and accompanying text.

70. By "owner-manager" I mean an individual who is active in the management of the corporation and who has a substantial ownership interest in the corporation.

71. By "professional managers" I mean full-time employees of the corporation, presumably executive officers, who do not own a substantial portion of the corporation's stock.

72. By "independent director" I mean a person who does not earn his living directly through salary or indirectly through business relationships from the corporation. Defining independence more concretely, however, is difficult. One approach has been to define the concept by exclusion. S. 2567, 96th Cong., 2d Sess. (1980), recently introduced by Senator 
sis suggests that none of the incumbents in these three categories has an incentive to continue the defense by delaying the inevitable shift in board control. An independent director should certainly recognize the potential for time-consuming and expensive litigation brought by a successful offeror intent on securing board control. Free of the ties that may encumber other categories of directors, an independent director has no reason to fight a fall-back action in the face of both inevitable defeat ${ }^{73}$ and the ideology of majority rule.

Professional management would also have little reason to go down with the ship. Their behavior during and after a tender offer can be expected to have a significant impact both on the likelihood of continued employment with the target following a shift in control of the board and on employment prospects with other firms. ${ }^{74}$ While loyalty and a commitment to a tenacious takeover defense could make a manager an attractive employee to other potential targets, one must wonder whether this extends to activity occurring after the

Howard Metzenbaum, simply requires that a majority of the members of the board of directors of the large corporations that would be subject to the bill not fall within any one of five categories: current employees; family of executive officers; outside counsel to the corporation; suppliers or dealers of the corporation; or individuals associated with the corporation's investment banker or other supplier of goods or services valued at more than $\$ 10,000$. Id . $\S 5(b)(1)-(5)$. A similar approach to labeling board nominees for proxy statement purposes was proposed but not adopted by the SEC. Securities Exchange Act Release 34-14970, Proposed Rules Relating to Shareholders Communications, Shareholder Participation in the Corporate Electoral Process and Corporate Governance Generally, reprinted in [1978 Transfer Binder] FED. SEC. L. REP. (CCH) I 81,645 (July 18, 1978); see also Corporate Director's Guidebook, 33 Bus. LAw. 1591 (1978).

The complexity of the definitional problem can be illustrated by considering the independence of what might appear to be the prototypical independent director: a professor of corporate law at a leading law school who has no other connection with the corporation. Speculating on the relationship between annual director fees for a corporation of the size covered by S. 2567 and a typical law school faculty salary, one could well wonder why the academic-whose total annual income may depend significantly upon his or her directorship-is presumed economically more independent than a partner in a major law firm that receives annual fees of $\$ 10,001$ from the corporation. See generally SENATE CoMM. ON BANKing, Housing and Urban Affairs, 96Th Cong., 2D Sess., Staff Report on Corporate ACCOUNTABILITY TO THE SECURITIES AND EXCHANGE COMMISSION A7-11, F21-44 (Comm. Print 1980); Small, The Evolving Role of the Director in Corporale Govemance, 30 Hastincs L.J. 1353 (1979). Even these complexities, however, raise questions concerning only economic independence. Issues of allocation of responsibility between management and shareholders also raise questions of ideological independence not measurable by reference to financial ties to the corporation. See Gilson, supra note 2, at 881 n.220.

73. See notes 18-31 supra and accompanying text.

74. The operation of a market for managerial services as a constraint on the discretion of senior management is considered in detail in Fama, Agency Problems and the Theory of the Firm, 88 J. POL. ECON. 288 (1980). See also R. POSNER, supra note 65, at 302; Werner, Management, Slock Market and Corporate Reform: Berle and Means Reconsidered, 77 Colum. L. REV. 388, 403 (1977). 
defense has failed. Moreover, professional managers remain in a position to sell their future services to the offeror, just as shareholders sell their shares, and thereby secure a portion of the benefits of the transaction. Because any payment for resignation from the board would be difficult if not impossible to distinguish from a legitimate payment for future services, the rational reaction by professional management would be surrender, albeit at a price. ${ }^{75}$ In this sense, the potential for delay may operate more as a means to allocate the pie between target management and target shareholders than as a way to discourage an offeror.

The only directors who might have an interest in holding out "to the last man" are owner-managers-substantial shareholders and often founders of the concern-who likely draw substantial nonmonetary benefits from their controlling positions in an independent concern, and who simply do not look forward to evaluation of the quality of their performance by a different owner. Even here, however, one must doubt the wisdom and, hence, the likelihood of recourse to the mechanisms provided by incumbency amendments. While there is an incentive to successfully defend the target's independence, there is no reason to continue the fight-to the individual's financial disadvantage-when it has already been lost. Thus, while a target bristling with hostility before the offer may deter even if the individual quills are not alarming, ${ }^{76}$ once the offer succeeds one would expect rational owners to secure whatever compensation they can for their cooperation. ${ }^{77}$

75. It might be possible, however, in effect to prepay existing management to act in what would otherwise be an irrational manner. If, for example, target management were given employment contracts guaranteeing, in the event of a successful takeover, either their continued employment at a substantial salary or the right to quit and receive a substantial lump-sum payment, an offeror might have reason to believe that the fight would continue to the bitter end. The target would, of course, encounter a problem of moral hazard; at some point the lump-sum payment following takeover becomes more attractive than continued control. A classic example of this phenomenon is the recent award of what have been styled "golden parachutes" to top executives of Conoco, Inc. Following the expression of interest in the company by such suitors as Seagram Co., Cities Service Co., and Texaco Inc., new employment contracts were awarded to senior management granting the chairman of the board, for example, the right to quit and receive a $\$ 5,000,000$ lump-sum payment if Conoco were taken over. Conoco Protects Nine of Its Top Officers With Takeover Compensation Agreements, Wall. St. J., July 9, 1981, at 4, col. 2. This arrangement would be prohibited by my rule barring postoffer defensive tactics. See Gilson, supra note 2, at 879.

76. The information content, in contrast to the operative effect, of shark repellent amendments is considered in notes 100-09 infra and accompanying text.

77. The common phenomenon of target management turning to a white knight following an initial offer, and the fact that a company that is a raider in one transaction may be a white knight in the next, suggest the accuracy of this prediction. 
In sum, the logic underlying the asserted deterrent effect of charter amendments designed to impede transfer of control of the board of directors is substantially flawed because it is based on the expectation that incumbent directors will act irrationally.

\section{Barriers to second-step transactions.}

Effectiveness in preventing freezeout mergers. Because its effectiveness does not depend on the behavior of individuals whose self-interest is inconsistent with the desired result, an amendment preventing second-step transactions has more promise as a deterrent than one directed at maintaining the incumbent board of directors. If a supermajority requirement for a second-step transaction is waivable only by "continuing directors"-effectively the preoffer board-the resignation or replacement of the incumbent board will not render the amendment ineffective. In that event the supermajority requirement may not be waivable at all. ${ }^{78}$

Because the goal of an offeror to whom a second-step transaction is important is, by definition, to acquire all of the target's stock, ${ }^{79}$ the initial impact of a supermajority amendment-to cause the offeror to increase the number of shares sought by tender to an amount in excess of the supermajority required-is not itself a serious burden. The potential for deterrence arises, however, from the possible increase in the total cost of the transaction even if the offeror had intended to pay the same price in the second-step transaction. If the supply curve for the target's stock is upward-sloping, the need to acquire a greater number of shares will result in an increased price not only for the marginal shares acquired due to the supermajority requirement, but, because the Williams Act requires the same price to be paid for all shares tendered, ${ }^{80}$ for the original shares as well. ${ }^{81}$

78. This conclusion depends, of course, on the presence of a lock-up amendment. See notes 55-65 supra and accompanying text.

79. There is no need to consider the impact of a supermajority amendment on an offeror with no intention of a second-step transaction; obviously the amendment could have no deterrent effect in that setting.

80. See Securities Act Release No. 6159, Securities Exchange Act Release No. 16,385, supra note 7 (interpreting Exchange Act $\S 14(d)(7), 15$ U.S.C. $\$ 78 n(d)(7)(1976)$, to require the same price be paid for all shares).

81. The notion of an upward-sloping supply curve for the target's stock is not inconsistent with existing empirical evidence suggesting that because shares of stock represent only a right to a future income stream with a particular risk-return relationship, as to which a multitude of substitutes exist, more or less of a security can be purchased without a resulting change in price. Scholes, The Market for Securities: Substitution versus Price Pressure and the Effects of Information on Share Prices, 45 J. Bus. 179 (1972). Professor Scholes points out that particular purchases or sales may reflect new information concerning the issuer which warrants altera- 
The alteration in offeror strategy required by a supermajority provision may also increase the cost of the total transaction through its impact on the type of consideration used and the amount of financing necessary for the complete acquisition of the target. It is not uncommon for an offeror to make an initial cash tender offer for a bare majority of the target's outstanding shares, expecting that its securities will be the consideration in the second-step transaction. ${ }^{82}$ This approach reduces the cash cost of the acquisition to the offeror and benefits the target shareholders by providing them the option of a tax-free exchange. ${ }^{83}$ Increasing the number of shares that must be acquired in the initial offer to satisfy the supermajority requirement raises the cash cost of the acquisition and, necessarily, the cost of the financing necessary to complete it. It may also reduce the opportunity to offer target shareholders the choice between a taxable and tax-free exchange, a benefit which presumably must be replaced if the transaction is to remain equally attractive to shareholders.

The deterrent potential of supermajority amendments obviously increases where target management itself owns or controls enough shares to block the supermajority vote even if the offeror tenders for all the outstanding shares. ${ }^{84}$ However, as with the efficacy of shark

tion in the price of its shares relative to substitutes. A tender offer may be the most extreme example since the offer to purchase reflects information that, for at least one buyer, there are no substitutes for the security, thus allowing a much greater role for price as opposed to substitution effects.

82. See, e.g., Freund \& Easton, supra note 2; Nathan, Developments in Stralegies and Taclics for Offerors in Merger, Tender Offer, and Similar Acquisition Transactions, in TENTH ANNUAL INSTITUTE ON SEGURITIES Regulation 257 (1979).

83. One attraction of a cash tender offer for a portion of the target's shares followed by a second-step merger in which the consideration offered would be the offeror's securities is to allow target shareholders to choose between a taxable and tax-free transaction. Shareholders electing to tender their shares in the initial cash offer would recognize gain or loss on the sale. Under current standards, the second-step merger would still qualify as an " $A$ " reorganization, see I.R.C. $\$ 368$ (a)(1)(A) (1976), with the result that target shareholders participating in the second-step transaction would not recognize gain or loss on their receipt of offeror securities, so long as approximately $50 \%$ of the target's securities are acquired in exchange for the offeror's securities in order to satisfy the continuity of interest doctrine. See Rev. Proc. 77-37, 1977-2 C.B. 568; 1 M. LIPTON \& E. STEINBERGER, supra note 1, at 115-18 (Supp. 1979).

For a discussion of other techniques intended to allow shareholders an individual choice between recognition and nonrecognition, see Bowen, Corporate Acquisition Techniques, $32 \mathrm{MA}$ JOR TAX Plan. II 101.3 (1980); Milefsky, The Hybrid Acquisition: A New Tax Concept in Acquisition Planning, MERGers \& ACQUisitions, Fall 1980, at 23.

84. See note 41 supra. A review of the disclosures in the proxy statements referred to in note 41 , as well as that in others in which management holdings, while insufficient alone to block a supermajority vote, are large enough to provide an effective veto, reveals wide variety in the manner in which management's control is disclosed or, indeed, whether it is specifically disclosed at all. It is impossible to determine whether the difference in disclosure with respect to an obviously material fact results from differing quality of staff review of particular proxy 
repellent amendments protecting the incumbent board of directors, the deterrent effect of management power to block a second-step transaction depends not only on the existence of the power, but also on the offeror's evaluation of management's will to use it in the face of a successful tender offer for a controlling, but not supermajority, interest. From this perspective, it must be kept in mind that target management pays a substantial price by exercising its power to block the second-step transaction. While such an action prevents the offeror from securing the potential benefits from eliminating minority shareholders, members of management will then remain minority shareholders with sharply reduced opportunities to liquidate their investment. Thus, the deterrent effect of the provision again depends, in part, on the offeror's willingness to believe that management will act in a financially irrational manner. Indeed, if one assumes that management's investment in the shares used to block the supermajority vote represents a significant portion of each manager's assets-a not unreasonable assumption with respect to professional management-the behavior necessary for the provision to operate as an effective deterrent is even more irrational than for incumbency amendments.

Importance of second-step transactions. Evaluation of the deterrence created by supermajority requirements thus far has assumed that the availability of second-step transactions is critical to the offeror. To the extent this assumption overstates the importance of these transactions to the offeror, the potential deterrence of even a perfectly effective amendment ${ }^{85}$ is reduced. In fact, on examination the reasons commonly offered for the desirability of a second-step transaction, ${ }^{86}$ although real, hardly seem compelling. The constraints on a parent's discretion in allocating synergistic benefits between itself and its subsidiary with public shareholders do not appear to be substantial. ${ }^{87}$

statements despite the standards imposed in Securities Exchange Act Release No. 15,230, supra note 7, or whether issuers are taking advantage of the fact that proxy material, unlike registration statements under the Securities Act of 1933, need not be declared effective by the SEC, but may be sent to shareholders, regardless of the character of staff comments, following a 10-day waiting period. See 17 C.F.R. \$ 240.14a-6 (1981).

85. One can imagine a form of shark repellent that could be effective at blocking a second-step transaction. A very high vote requirement together with a requirement for approval by a majority of nontendering shareholders, see note 41 supra, and with no exceptions other than approval by the target board prior to the offeror's acquisition of a significant percentage of target shares, see note 45 supra, might make a second-step transaction impossible even if target management conceded after the success of the initial offer.

86. See notes $46-48$ supra and accompanying text.

87. See note 93 infra. 
The administrative costs associated with public shareholders, while nontrivial, ${ }^{88}$ are hardly large enough to affect a transaction of significant size. Finally, the available empirical evidence strongly suggests that the offeror's return comes from the right "to control . . . the target's resources," 89 not from a postoffer increase in the value of the target's shares. ${ }^{90}$ This, of course, would counsel against a second-step transaction, because once the offeror achieves control, its rate of return on the investment may well decrease with the purchase of additional shares.

Nonetheless, from a different perspective of the tender offer process, the ability to effect a second-step transaction may retain its importance. That an offer is made reflects the offeror's view that after completion of the transaction the value of the shares acquired will exceed the price to be paid. ${ }^{91}$ A rational shareholder might then decide not to tender, but to "free-ride" on the offer. Thus, one might argue that the ability to freeze out these free-riders at a price not reflecting the offeror's anticipated profits is crucial to the offer's success. ${ }^{92}$

But a second-step transaction is not the only way to prevent target shareholders from free-riding on the offeror's profits. Whether an offeror's anticipated profit results from synergy or the displacement of inefficient management, current case law presents little barrier to

88. See note 47 supra and accompanying text.

89. Jarrell \& Bradley, The Economic Effects of Federal and State Regulations of Cash Tender offers, 23 J.L. \& ECON. 371, 381-82 (1980).

90. See note 94 infra.

91. The condition commonly considered necessary to induce a tender offer is that the value to the offeror of the shares acquired exceeds the price paid plus transaction costs. See, e.g. , Grossman \& Hart, supra note 65; Kummer \& Hoffmeister, Valuation Consequences of Cash Tender Offers, 33 J. Fin. 505 (1978); Smiley, Tender Offers, Transactions Costs and the Theory of the Fim, 58 ReV. ECON. \& StATistics 22 (1976).

92. Grossman \& Hart, supra note 65 , argue that no takeover will occur unless the value of the shares after the offer exceeds the price paid by the offeror plus transaction costs. But this excess

represents a profit shareholders could have made if they had not tendered their shares to the raider. In particular, suppose each shareholder is so small that his tender decision will not affect the outcome of the raid. Then, if a shareholder thinks that the raid will succeed and that the raider will improve the firm, he will not tender his shares, but will instead retain them, because he anticipates a profit from their price appreciation.

Id. at 43. The authors argue that no takeovers will succeed in the absence of mechanisms to discourage free-riders. The ability to eliminate minority shareholders at a price that does not reflect the increased value resulting from the transaction is the most obvious means to do this. Grossman and Hart argue that the incentive to make a tender offer at a premium is reduced if the ability to freeze out minority shareholders at an unfavorable price is constrained. Id. at 44-47. 
the offeror's retaining a disproportionate amount of the profit. ${ }^{93}$ Anticipation of such behavior by the offeror should dissuade target shareholders from free-riding in expectation of an increase in the price of their shares following a successful tender. Empirical investigation is consistent with this analysis, suggesting that the market price of a target's stock following a successful offer drops below the offer price, ${ }^{94}$ and that the offeror's gain results from an increase in the value of its own stock, an increase in which the minority cannot share by free-riding. ${ }^{95}$

In sum, shark repellent amendments creating a barrier to secondstep transactions have more promise as a deterrent than incumbency amendments. The significance of this barrier is attenuated by the reality facing target management when an offeror secures majority, but not supermajority, control, and by doubts about the overall importance of the second-step transaction to the offeror. Still, to the extent that a second-step transaction is desirable, these provisions retain the potential, because of Williams Act requirements, for disproportionately increasing the cost of the offer by increasing the number of shares an offeror must acquire to accomplish it. ${ }^{96}$

\section{Fair price and compulsory redemption provisions.}

Fair price amendments act as a backstop to supermajority barriers to second-step transactions. Although they can help the overall

93. The opportunities for a parent company to favor itself at the expense of the subsidiary are legion, and " $[t]$ he checks on unfair dealing by the parent are few. In theory, of course, the fairness of the parent's behavior, is subject to the check of judicial review; but in practice such review is difficult even where the courts have the will to engage in it, and they often lack the will." M. EISENBERG, supra note 46, at 309 (citations omitted); see Brudney, Efficient Markets and Fair Values in Parent Subsidiany Mergers, 4 J. CoRP. L. 63, 69-71 (1978); Cary, supra note 52 , at $679-83$.

94. The data concerning the size of the premium paid in a tender offer, and the extent of the postoffer increase in the price of the target's stock, are consistent with the offeror according itself, presumably through inter-company transactions and charges, a disproportionate share of the benefits resulting from the acquisition. If the offeror gained only through the increased value of the target's stock following the acquisition, the postoffer value of target stock would have to exceed the price paid by the offeror. Minority shareholders would then share equally with the offeror in the gains resulting from the transaction. In fact, postoffer prices average some $13 \%$ below the tender price, Bradley, Interfirm Tender Offers and the Market for Corporale Control, $53 \mathrm{~J}$. Bus. 345, 364 (1980), strongly suggesting that offerors gain from the acquisition in ways which exclude the participation of minority shareholders. For an examination of this evidence and its relationship to an offeror's motivation for engaging in the transaction, see Gilson, supra note 2, at 873-75.

95. Under this explanation, the increase in the price of the offeror's stock results from the "right to control of the target's resources." Jarrell \& Bradley, supra note 89, at 381-82.

96. See notes 80-81 supra and accompanying text. 
package of amendments to appear more balanced by providing a means to avoid the supermajority requirement, the formulas contained in these amendments may increase the price required to be paid in the second-step transaction, perhaps to a level above the initial tender price, so that the option is illusory. Because fair price amendments focus only on second-step transactions, their effectiveness as a deterrent, like that of supermajority requirements generally, depends on the belief that target management will choose to enforce the requirements, on the size of the resulting increase in total acquisition cost, and ultimately on the overall importance of a second-step transaction to the offeror.

Right of redemption provisions, in contrast, promise greater deterrence than either supermajority or fair price amendments. Like fair price amendments, right of redemption provisions make the entire acquisition more expensive by increasing the price of the secondstep transaction. But they go a step further by removing the offeror's alternative of not proceeding with a second-step transaction if its cost appears too great or its benefits too small. Right of redemption provisions thereby institutionalize the free-rider problem that I argued was not significant with respect to second-step transactions alone. If shareholders understand that a successful tender offer will give them the right to demand a higher price for their shares-a fact target management might be expected to disseminate with enthusiasm ${ }^{97}$ there is no avoiding the incentive to hold out in the hope that other shareholders will tender and the offer will succeed. ${ }^{98}$

97. See note 54 supra.

98. The classic example is that of a closed-end mutual fund. Although the only assets held by the fund are the securities of other companies, so that net asset value and liquidation value are virtually identical, the securities of many of them, for significant periods of time, have traded at a price below net asset value. See generally Boudreaux, Discounts and Premiums on Closed-End Mutual Funds: A Study in Valuation, 28 J. FIN. 515 (1973); Malkiel, The Valuation of Closed-End Investment-Company Shares, 32 J. Fin. 847 (1977); Mendelson, Closed-End Fund Discounts Revisiled, 2 Fin. REV. 48 (1978). Thus, one acquiring control of the fund at market price and liquidating it would profit by the amount of the pre-existing discount from net asset value. But a shareholder who believed that the offer would be successful would refuse to sell for a premium less than the full discount since, on liquidation, the shareholder would receive the full benefit. Grossman \& Hart, supra note 65 , at 57 . Bradley argues that an offeror can avoid this quandary and profit from the transaction despite the discount to target shareholders, because "the acquisition yields an interactive (synergistic) gain that can be shared by the stockholders of both firms." Bradley, supra note 94, at 354 n.9. The difficulty with this explanation is that because the fund's assets are solely other securities, and because elimination of the discount is based on the expectation that the fund will be liquidated, it is unlikely that the transaction will have the synergistic effect of increasing the value of the existing assets of the offeror. While one might suggest that the offeror gains through an ability to earn future income as the fund's investment adviser following the transaction, see Rosenfeld v. Black, 445 
Thus, of the categories of shark repellent amendments, right of redemption provisions, the type least frequently adopted, present the greatest potential for deterring an offeror. ${ }^{99}$

\section{Shark repellent amendments as "corporate signals."}

I have demonstrated that the direct deterrent effect of the most common shark repellent amendments has been greatly exaggerated. But even where shark repellent amendments are not effective on their own terms, there is an argument that they may nonetheless serve to steer offerors away. The idea is that their deterrence derives not from the actual effect of the amendments, but from what the amendments suggest about the target's future actions. This view of shark repellent amendments is based upon developments in "signaling theory," which posits that the information value of certain corporate behavior is not in the action taken, but in what that action "signals" about attributes of the corporation not otherwise discernible at that time. ${ }^{100}$ Thus, for example, it is argued that investors may respond favorably to a more highly leveraged financial structure, despite the accepted theory that firm value is determined by the present value of future income streams regardless of the firm's debt-equity ratio, ${ }^{101}$ if investors perceive that increased leverage reflects that management has

F.2d 1337 (2d Cir. 1971), cert. dismissed, 409 U.S. 802 (1972), that explanation is inconsistent with elimination of the discount through liquidation, although it is possible if the discount is eliminated through conversion to an open-end fund.

99. It is interesting that the form of shark repellent amendment most likely to be an effective deterrent is also the one that is most justifiable from the perspective of target shareholders. The available empirical evidence strongly suggests that the principal source of gain for the acquiring corporation is the allocation to itself of a disproportionate amount of the benefits arising from the transaction. See Gilson, supra note 2, at 874-75; note 94 supra. The right of redemption provision can be responsive to the plight of the "frozen-in" shareholder. See note 52 supra.

100. For the application of signaling theory in a variety of contexts, see, e.g., A. SPENCE, MaRket Signaling: INFormational TRANSFer In Hiring and Related Screening Processes (1974); Akerlof, The Market for "Lemons": Quality Uncertainty and the Market Mechanism, 84 Q.J. ECON. 488 (1970); Gonedes, Corporale Signaling, Extemal Accounting, and Capital Market Equilibrium: Evidence on Dividends, Income, and Extraordinary Items, $16 \mathrm{~J}$. ACCT. RESEARCH 26 (1978); Grossman \& Hart, Disclosure Laws and Takeover Bids, 35 J. FIN. 323 (1980); Ross, Disclosure Regulation in Financial Markets: Implications of Modem Finance Theory and Signaling Theory, in Issues in Financial Regulation 177 (F. Edwards ed. 1979); Ross, The Determination of Financial Sinucture: The Incentive Signalling Approach, 8 BELL J. ECON. 23 (1977) [hereinafter cited as Ross, Determination of Financial Siructure].

101. The text restates broadly the Modigliani-Miller irrelevancy propositions. See Miller \& Modigliani, Dividend Polig, Growth, and the Valuation of Shares, 34 J. BuS. 411 (1961); Modigliani \& Miller, The Cast of Capital, Corporation Finance and the Theory of Investment, 48 AM. ECON. REV. 261 (1958). 
favorable nonpublic information about the firm's future. ${ }^{102}$

In the context of defensive tactics, the signaling argument is that even though everyone knows that shark repellent amendments will not themselves deter an otherwise interested offeror, they do represent a way in which management can communicate to the universe of potential offerors before an offer is made, and therefore at a time when the communication can still affect the potential offeror's behavior. The message is simply that the company intends to defend itself vigorously against any offer. While the shark repellent amendments themselves may not be effective, their adoption tells the potential offeror that other action, which cannot be taken until an offer is made - such as a scorched earth defense-will be undertaken. ${ }^{103}$

This application of signaling theory is questionable. For a signal to be effective-to "reflect information about the unobservable attributes of firms' decisions"104_it must be clear what attribute is being disclosed. No clear message appears to be sent by adoption of shark repellent amendments. While some commentators state that shark repellent amendments have an "in terrorem effect: . . . a signal to a would-be raider that it might better look elsewhere if it wishes to avoid a spirited struggle," 105 others suggest that their adoption is a sign of weakness, and testify to a "growing feeling that . . . these charter provisions are counter-productive in that they call attention to the company as a prospective target." 106 A further condition to a signal's effectiveness is that it must "facilitate distinguishing between firms whose decisions have different unobservable characteristics."107 The difficulty with shark repellent amendments is their popularity; ${ }^{108}$ as more and more firms adopt them, they no longer distinguish between firms that will react passively and those that will react ag-

102. Ross, Determination of Financial Structure, supra note 100, at 25. This position is arguably consistent with the Modigliani-Miller irrelevancy propositions since the propositions only apply to firms of a common risk class. The effect of the signals inherent in the financial structure, it is argued, is to shift "the market's perception of the firm's risk class." Id. at 36. For a criticism of this approach from the perspective of a securities lawyer, see Kripke, Commentary, in Issues IN FiNANGIAL Regulation, supra note 100, at 203.

103. E.g., Hochman \& Folger, supra note 6, at 537; Lipton, Takeover Bids in the Target's Boardroom, 35 Bus. LAw. 101, 110 (1979).

104. Gonedes, supra note 100 , at 27.

105. Hochman \& Folger, supra note 6 , at 537.

106. 1 M. LIPTON \& E. STEINBERGER, supra note 1, at 266.

107. Gonedes, supra note 100 , at 30 .

108. Black and Smith, supra note 6, report that between 1972 and 1978, 199 companies listed on the New York Stock Exchange adopted supermajority provisions of one sort or another. Id. at 713 n.51. 
gressively, and so the value of the signal diminishes. ${ }^{109}$

My review of shark repellent amendments demonstrates that the most common amendments are likely to be very weak deterrents. But that is not to say that they are unimportant. Tender offer decisions, like all business choices, are made at the margin. An increase in acquisition costs resulting from shark repellent amendments need not alone make a proposed acquisition undesirable; it need only be the last straw. Thus, even largely ineffective shark repellent amendments may deter a particular transaction in some circumstances, to the detriment of the target's shareholders. ${ }^{110}$ If that result can be avoided without substantial regulatory cost, the effort is worthwhile.

\section{Traditional Approaches to Shark Repellent AMENDMENTS: ATTACK AND DEFENSE}

\section{Unlike other defensive tactics, ${ }^{111}$ most shark repellent amend-}

109. In light of recent developments in statistical methods, it is now possible to determine empirically whether the market believes that the adoption of shark repellent amendments reduces the likelihood of a future tender offer-whether because of the effectiveness of the amendments themselves, or because adoption carries with it information concerning management's intentions if a tender offer is made. Because any future offer would be made at a premium, the preadoption market price of the company's stock should reflect the expected premium discounted by estimates of the probability of an offer and of how far in the future the offer will occur. Thus, the adoption of a shark repellent amendment should result in a decrease in the price of the stock relative to the market as a whole if adoption is believed to reduce the likelihood of a future premium offer. Using what is called the "market model," see, e.g., E. Fama, Foundations of Finance 63-132 (1976); G. Foster, Financial StateMENT ANALYSIS 362-65 (1978), one can distinguish the impact on price caused by the adoption of the shark repellent amendment from that of other events affecting the company.

An effort of this sort was attempted by H. DeAngelo \& E. Rice, Anti-Takeover Charter Amendments and Stockholder Wealth (Working Paper No. 7, Graduate School of Business Administration, University of Washington) (1980), with a sample of amendments adopted by 87 companies between 1974 and 1979. Their evidence indicated a slight decrease in returns to companies adopting shark repellent amendments, but the decrease was not statistically significant. While this is consistent with my conclusion that shark repellent amendments are unlikely to be very effective, the DeAngelo \& Rice study is sufficiently flawed that its results cannot be taken as conclusive. Among other difficulties with the design of the study, approximately $15 \%$ of the sample consisted of charter amendments involving only incumbency provisions, which, I have argued, are the least likely to deter a potential offeror. See notes 69-77 supra and accompanying text. In addition, some amendments in the sample did not include a lock-up provision. H. DeAngelo \& E. Rice, supra, at 23. Since it is only the presence of a lockup amendment or a comparable statutory provision, see, e.g., N.Y. BuS. CoRP. LAw § 616 (McKinney 1963), that provides even the potential for deterrence, see notes 55-65 supra and accompanying text, this problem would also bias the results toward ineffectiveness.

110. Gilson, supra note 2, at 848-65, and Easterbrook \& Fischel, supra note 13, at $1182-94$, rebut arguments that deterring tender offers in one fashion or another benefits target shareholders.

111. See Gilson, supra note 2, at 826-31. 
ments have the advantage of clarity of intent: Their only purpose is to reallocate decisionmaking power over tender offers in favor of management. A typical proxy statement disclosure states that the proposed shark repellent amendments "are designed to discourage any attempt to obtain control of [the target] in a transaction which is not approved by [the] Board of Directors."112 The unavoidable consequence of this reallocation is to make incumbent managers more secure in their positions: "[S]uch amendments may result in the incumbent officers and directors ... retaining their positions even though stockholders holding a majority of shares desire a change."113 Management's role in the adoption of shark repellent amendmentswhether by investing corporate resources in their development, by using proxy machinery to solicit their approval, or simply by recommending their adoption-therefore raises the question of whether management has acted in its own interest at the expense of the shareholders. In traditional terms, the obvious attack on management's activities would be framed in terms of a violation of fiduciary duty.

The obvious response is also traditional. The corporate statutes of most states expressly authorize the most common forms of shark repellent amendments. In modern "enabling act" statutes, ${ }^{114}$ phrases such as "unless otherwise provided in the articles of incorporation" qualify almost all prescriptive provisions, ${ }^{115}$ and all major statutes expressly authorize supermajority voting requirements. ${ }^{116}$ Subject only to compliance with the required formalities concerning amending the articles of incorporation, ${ }^{117}$ it would be argued, the validity of

112. Proxy Statement of PSA, Inc., supra note 28 , at $400-4$. Similar statements appear in the proxy statements of many companies proposing shark repellent amendments. See, e.g., Proxy Statement of Baldor Electric Co., supra note 41, at 400-23 to -24; Proxy Statement of Ozark Airlines 4 (Apr. 16, 1979); Proxy Statement of Sterling Precision Corp. 14-15, 16 (Aug. 23, 1979).

113. Proxy Statement of PSA, Inc., supra note 28; see Proxy Statement of Sterling Precision Corp., supra note 112 , at 18.

114. An "enabling act" is one that explicitly allows those forming a corporation the freedom to structure their arrangement as they choose, "put[ting] the arrangements for the allocation of risk, control, profit, and residual ownership on a free contract basis," Latty, supra note 17 , at 601 , and provides "relatively unhampered procedures . . . to meet changing conditions by effecting changes in the corporate purposes and security structures," Katz, The Philosophy of Midcentury Corporation Statutes, 23 LAW \& CONTEMP. PROB. 177, 179 (1958).

115. E.g., CAL. CoRP. CODE $\S \S 602(a), 603(a), 1201$ (a) (West 1977 \& Supp. 1981); DeL. CODE ANN. tit. 8, $\$ \$ 212(a), 215,223($ a), (d) (1974).

116. Cal. Corp. Code § 204(a)(5) (West Supp. 1981); Del. Code ANN. tit. 8, $\S 102(b)$ (4) (1974); N.Y. BUS. CORP. LAW $\S 616(a)$ (2) (McKinney 1963); ABA-ALI MODEL Bus. CORP. ACT. ANN. 2D $\$ 145$ (1971).

117. Amending the articles of incorporation commonly requires approval by the board of directors, an affirmative vote of the shareholders, and an appropriate filing with a desig- 
shark repellent amendments is unassailable. ${ }^{18}$

In fact, both traditional fiduciary analysis and technical statutory construction are unsuitable for resolving the problem posed by shark repellent amendments. As I have argued elsewhere, ${ }^{119}$ the prevailing measure of fiduciary obligation is virtually without content where the conflict of interest triggering its application concerns the maintenance of control. Similarly, analysis limited to technical construction of statutory language is incapable of confronting the issue of management's appropriate role in conflicts over corporate control. As Charles Black has argued concerning an analogous problem, it is not helpful to get "out dictionaries whose entries will not really respond to the question we are putting, or scanning utterances, contemporary with the text, of persons who did not really face the question we are asking. We will have to deal with policy and not with grammar."120

The remainder of this Part demonstrates that a traditional attack on the validity of shark repellent amendments is likely to be ineffectual and that the statutory defense offered on their behalf is simply unconvincing. Both points are independently worth making and, in any event, are a necessary way station on the road to a structural analysis of shark repellent amendments.

nated state official. See, e.g., Gal. CORP. CODE $\$ \S 902,905$ (West 1977 \& Supp. 1981); DeL. CODE ANN. tit. 8, §§ 241, 242, 245 (1974 \& Supp. 1980); N.Y. Bus. CoRP. LAW $\S \S 801,805$ (McKinney 1963 \& Supp. 1981-1982).

118. See notes 132-43 infra and accompanying text. Unusual forms of amendments, however, may raise particular issues not so clearly covered by the text of the applicable corporate statute. E.g., Proxy Statement of Foremost-McKesson, Inc. 30-31 (June 17, 1980) (grant of power to "Board of Directors to restrict and limit the transfer to, and the purchase, ownership, and voting of shares by, or on behalf of a particular stockholder to the extent and for the period of time that: (i) the Corporation is directed in writing to do so by a governmental authority or (ii) to the extent the Board of Directors otherwise deems necessary, based on written advice received from any such governmental authority, that it takes such action in order to avoid the suspension, revocation, loss or forfeiture of, or refusal to renew or reissue, a license, franchise, grant of authority, line of business, right or benefit."); see also Joseph E. Seagram \& Sons, Inc. v. Conoco, Inc., 519 F. Supp. 506 (D. Del. 1981) (validity of amendment barring alien stock ownership). Seagram is discussed in note 131 infra.

Of the more familiar forms of amendments, the problem of applying the corporate statute is most acute with right of redemption provisions. For example, there are questions under some corporate statutes of whether common stock may be made redeemable. In addition, legal capital-type restrictions may prevent redemption at the time the amendment is triggered. See Mestres \& Gerlits, Tender Offers: Considerations for the Defense, in ELEVENTH ANNUAL INSTITUTE ON SECURTIIES REgULATION 49, 75-76 (1980); Smith, supra note 6, at 25.

119. Gilson, supra note 2, at 825-31.

120. C. Black, Structure and Relationship in Constitutional LaW 22-23 (1969). 


\section{A. The Application of the Fiduciary Principle in Control Settings}

I have previously traced the common law development of the fairness test-the measure of management's discharge of its duty of loyalty in conflict of interest settings-and argued that the courts have cleverly avoided confronting the obvious and unavoidable conflict of interest posed by a potential change of control. ${ }^{121}$ Typical defensive tactics undertaken by management facing a challenger for control include repurchasing the insurgent's shares at a premium over market price and placing newly issued shares in the hands of an ally, either of which effectively blocks management's displacement. In both settings, the fairness test could be applied to the terms of the transaction. In the repurchase case, inquiry could be made into the fairness of the price the company pays for its shares, and in the placement case, the fairness of the price the company receives for its shares could be examined. In both cases, however, such an inquiry completely misses the point. Management's conflict of interest does not arise from the price assigned to the company's shares in the transaction, but from having undertaken the transaction at all. "Applying a fairness standard to this decision, however, requires a court to determine whether it was 'fair' for control to remain with management rather than shift to the offeror. And this inquiry must necessarily focus on whether the shareholders would be better off with existing management or by selling their shares." 122 Quite appropriately, the courts have been unwilling to engage in such analysis. ${ }^{123}$

In both the repurchase and the new issuance settings, the courts avoided confronting the conflict of interest necessitating the fairness review by inquiring into management's motives. ${ }^{124}$ If a court could conclude that management undertook the repurchase because of a conflict over business policy with the insurgent or because the transaction also served a legitimate corporate interest, the conflict of interest was exorcised. The measure of management's performance was then the business judgment test, in effect a conclusion that the management action in question would not be reviewed at all. ${ }^{125}$

In short, the courts avoided confronting management's conflict of interest in actual control contests by focusing on motive: Did management believe there was a policy conflict or believe that its action

121. Gilson, supra note 2 , at $824-31$.

122. Id. at 827.

123. Id. at $827-31$.

124. Id. at 827-29.

125. Id. at 822 . 
served a legitimate corporate purpose? Given that the courts thus avoided addressing management's real conflict of interest in actual control contests, ${ }^{126}$ it is hardly likely that they would find a violation of the duty of loyalty because of the impact on a future control contest of management's introduction of defensive charter amendments whose stated purpose is to protect the shareholders.

\section{B. Textual Analysis of the Validity of Shark Repellent Amendments}

Just as the duty of loyalty provides the traditional focus for an attack on the validity of shark repellent amendments, a textual analysis of the language of the corporate statute provides the traditional focus for their defense. This mode of analysis is straightforward and familiar: It argues that the language of the statute contemplates the challenged provision and that further inquiry is therefore unnecessary.

While this approach to the governing statute is useful in evaluating other questions of corporate law, ${ }^{127}$ it is not helpful when applied to the process by which control of a corporation is shifted. Technical analysis is by itself unconvincing. As others have pointed out, language of "constitutional" scope, such as in a corporate statute, often simply cannot bear the burden of resolving the character of a dispute without the assistance of a broader view. ${ }^{128}$ This section argues that despite the apparent precision of the corporate statute, it is not responsive to the control questions posed by shark repellent amendments. The next Part makes the broader argument that the validity

126. Recent cases have consistently taken this approach. See, e.g., Treadway Cos. v. Care Corp., 638 F.2d 357, 380-83 (2d Cir. 1980); Crouse-Hinds Co. v. Internorth, Inc., 634 F.2d 690 (2d Cir. 1980); Johnson v. Trueblood, 629 F.2d 287 (3d Cir. 1980); Panter v. Marshall Field \& Co., 486 F. Supp. 1168 (N.D. Ill. 1980), affd, 646 F.2d 271 (7th Cir. 1981). In light of Treadway and Crouse-Hinds, the more attractive language of Judge Weinfeld in Conoco, Inc. v. Seagram Co., 517 F. Supp. 1299, 1303 (S.D.N.Y. 1981) ("The [Conoco] Directors are free to continue by proper legal means to express to the shareholders their objection and hostility to the Seagram proposal, but they are not free to deny them their right to pass upon this offer or any other offer for the purchase of their shares."), would seem to be limited to the particular claim before the court: that Seagram's representations that it was only interested in a friendly transaction estopped it from later making a hostile offer. See also Walton v. Morgan Stanley \& Co., Inc., 623 F.2d 796 (2d Cir. 1980).

127. One value of a precisely written and rigidly construed corporate statute is that those dealing with the corporation have the benefit of a form contract which need be overridden only in the unusual case where a result different from that provided by the statute is desired. See R. POSNER, supra note 65, at 292-96; R. WINTER, GOVERNMENT AND THE CoRPORATION 6 (1978). Where there is uncertainty as to a court's likelihood of construing the language of the statute in light of its plain meaning, those dealing with the corporation will incur the expense of individually tailored contracts.

128. See C. BLACK, supra note 120 , at 22-23; M. EISENBERG, supra note 46 , at 85-86. 
of shark repellent amendments must depend on the overall corporate structure that derives not only from the statute, but from the relationships among corporate constituents and between the corporation and the outside world.

I have found only three cases that directly confront the validity of shark repellent amendments or their equivalents. Of these, Seibert $v$. Gulton Industries, Inc. ${ }^{129}$ and Providence $\mathcal{G}^{2}$ Worcester Co. v. Baker ${ }^{130}$ present useful examples of the technical approach to the claim that shark repellent amendments are invalid. ${ }^{131}$

129. Civ. Action No. 5631 (Del. Ch. June 21, 1979), summarily affd, 414 A.2d 822 (Del. 1980).

130. 378 A.2d 121 (Del. 1977).

131. The third case, Seibert v. Milton Bradley Co., 405 N.E.2d 131 (Mass. 1980), is a virtual replay of Seibert v. Gulton Industries, Inc., except that the latter raises the issue under the Delaware General Corporation Law while the former is concerned with the Massachusetts Business Corporation Law. The overall importance of Delaware corporate law as well as the greater familiarity of most lawyers with its provisions is the basis for my choice of Gulton for consideration in the text.

While these three cases stand alone in their direct consideration of the validity of shark repellent amendments, other cases have touched on the matter indirectly. In Joseph E. Seagram \& Sons, Ltd. v. Conoco, Inc., 519 F. Supp. 506 (D. Del. 1981), Seagrams challenged the validity of amendments to Conoco's bylaws which limited alien ownership by voiding stock transfer to an alien if that transfer would result in exceeding an applicable "Alien Permitted Percentage." The court elected not to reach the issue of the reasonability of the amendment, instead construing DEL. CODE ANN. tit. 8, § 202 (Supp. 1980), to bar the application of a transfer restriction to any shares outstanding prior to its adoption that had not voted in favor of the restriction. This construction had the effect of prohibiting the application of the bylaw amendment to any outstanding shares, since only the board of directors had approved it, and, due to difficulties of tracing share ownership, eliminated the value of such an amendment in a large public corporation even if approved by a majority of the shareholders. See Young v. Valhi, Inc., 382 A.2d 1372 (Del. Ch. 1978) (striking down an attempt by a successful offeror who was unable to obtain a supermajority for a second-step transaction to circumvent that requirement through a subsidiary merger, thereby implying that the supermajority requirement was viewed as unobjectionable); see also Elgin Nat'l Indus., Inc. v. Chemetron Corp., 299 F. Supp. 367 (D. Del. 1969) (challenge to adequacy of proxy disclosure concerning shark repellent proposals); McKee \& Co. v. First Nat'l Bank of San Diego, 265 F. Supp. 1 (S.D. Cal. 1967) (upholding validity of bylaw adopted during contest for control requiring, inter alia, that nominees for directors have been residents of San Diego County for one year and not be an attorney or otherwise connected with other banks); Telvest, Inc. v. Olson, Civ. Action No. 5798 (Del. Ch. Mar. 8, 1979) (available Mar. 9, 1982, on LEXIS, Del library, Chncry file) (directors alone cannot authorize class of preferred stock having $80 \%$ class vote requirement on mergers; shareholder vote required).

Although judicial consideration of the validity of shark repellent amendments has,been sparse, complaints filed which challenge their validity are common. Examples of these are set out as exhibits in A. FleISCHER, supra note 2, at 390-23; 2 M. LIPTON \& E. STEINBERGER, supra note 1 , at M-1. Like most litigation in the tender offer field, the complaints are largely strategic, Wachtell, supra note 3 , and do not ripen into decisions on the merits.

There have also been some state administrative efforts to discourage shark repellent amendments. Harold Marsh reports that "it is understood" that the California Secretary of State would not file a related person supermajority amendment under the pre-1977 California 
In Gulton, the plaintiff challenged the most common type of shark repellent amendment: a supermajority provision requiring an $80 \%$ shareholder vote for "a merger or consolidation or similar takeover"132 with anyone owning more than $5 \%$ of the company's shares unless the board of directors had approved the transaction before the acquisition of the $5 \%$ interest. ${ }^{133}$ Although the supermajority requirement had been adopted by a vote of only $54 \%$ of the shareholders, it was protected by a simultaneously adopted lock-up provision requiring an $80 \%$ vote for repeal or amendment. ${ }^{134}$ The plaintiff's attack on the supermajority provision focused on the role it assigned the board of directors. Conceding that the articles of incorporation could have required a supermajority vote for the covered transactions under all circumstances, ${ }^{135}$ she claimed that the Delaware General Corporation Law did not allow the percentage vote required to differ depending upon whether the board of directors had approved the transaction at the required time.

The court's analysis was pristinely technical. Section 102(b)(4) of the Delaware statute permits a corporation's certificate of incorporation to require a shareholder vote higher than the usual bare majority provided by the statute for "any corporate action."136 Completing the syllogism, the court concluded that Gulton's supermajority provision did no more than require a different share-

Corporations Code, and believes it likely that this practice will continue under the new Code. 1 H. Marsh, California Corporations LaW \& Practice $\$ 10.39$ (1977). In addition, the Wisconsin Commission on Securities has adopted regulations under the Wisconsin blue sky statute which allow prohibition of the sale of an issuer's equity securities if its charter contains shark repellent amendments. WIS. ADMIN. CODE § SEC 3.07(2) (1970, as amended), reprinted in 3 BLUE SKY L. REP. (CCH) I 64,527.

132. Gulton, slip op. at 2.

133. See note 45 supra and accompanying text.

134. The Gulton Industries Proxy Statement 8 (May 23, 1977) described the lock-up provision as follows:

At present, only the vote of a majority of the outstanding shares of the Company entitled to vote is necessary to authorize corporate transactions requiring stockholder approval or amendment of the Certificate of Incorporation. Under the proposed amendment . . . the holders of $21 \%$ of the outstanding shares of the Company would be able to prevent certain transactions or amendments to the Certificate of Incorporation even if the holders of $79 \%$ of the outstanding shares were in favor of such action.

135. Gulton, slip op. at 3. I am unwilling to make this concession. See notes $142-52$ infra and accompanying text.

136. DeL. CODE. ANN. tit. 8, § 102(b)(4) (1974). Id. § 251 contains the majority requirement for mergers and $\S 271$ for sales of assets. Section 242(a) authorizes amendment of the certificate of incorporation "in any and as many respects as may be desired, so long as [the] certificate of incorporation as amended would contain only such provisions as it would be lawful and proper to insert in an original certificate of incorporation." 
holder vote for a different "corporate action," precisely as authorized under section 102(b)(4). The percentage approval required was, in the court's words, "dependent upon the matter subject to the vote, i.e., a business combination with a 5 per cent shareholder approved by the board of directors or a combination with a 5 per cent shareholder opposed by the board."137 The supermajority amendment thus was expressly authorized by the language of the statute; finding no "public policy against the so-called 'shifting numbers' where corporate voting rights are concerned,"138 the court upheld the charter provision.

Simply as a matter of textual analysis, the court's construction of the statute is hardly persuasive. The argument reduces to an assertion that the amendment's shifting vote requirement satisfies the language of section 102(b)(4) because a merger which the board has not approved is a different "action" from one which it has approved. Regardless of one's position on the wisdom of such an amendment, the word "action" as it appears in the statute does not resolve the matter. A dictionary definition of the word refers to "a thing done"; 139 nothing in the text of the statute forecloses a construction that identifies the "thing" for which approval is sought as the merger, and rejects the exercise in subcategorization that distinguishes between types of mergers based on when approval of the board of directors is obtained. ${ }^{140}$ But more important, examination of the corporate statute alone is not responsive to the question posed by shark repellent amendments-the appropriate allocation of roles between directors and shareholders in a battle for control. ${ }^{141}$

137. Gulton, slip op. at 7. In fact, the court's formulation of the alternatives is incorrect. Under the form of exception contained in the Gulton Industries provision, the determining factor was not whether the board of directors approved the transaction, since the board must approve any merger, but whether the board had approved the transaction before or after the shareholder had acquired $5 \%$ of the outstanding stock.

138. Id. at 8-9.

139. WEBSTER's ThIRD New INTERNATIONAL Dictionary 21 (unabr. 1976).

140. The court's treatment of this issue in Seibert v. Milton Bradley Co., 405 N.E.2d 131 (Mass. 1980), was similarly linguistic. Responding to plaintiffs argument that the statutory authorization for a supermajority voting requirement did not allow differing votes depending on director approval, the court stated:

This argument is unpersuasive. According to $\S 8(\mathrm{a})$, the by-law controls "whenever" it requires a greater proportion of shareholders to vote for a particular proposal than the statute specifies. The plaintiff has ignored the word "whenever." The by-law specifies precisely "when" a 75\% shareholder vote rather than the statutory majority will be required. With the words "whenever" and "greater proportion" given their ordinary meaning, ... . the by-law fully complies with $\S 8(a)$.

Id. at 134 (citations omitted).

141. There is no indication in the court's opinion that it considered the allocation of 
It is necessary, however, to take analysis of the indeterminacy of the statutory language a step further. Some supermajority amendments do not provide for differing approval percentages based on director action. ${ }^{142}$ With respect to these amendments, the statutory language is not ambiguous: Section 102(b)(4) expressly authorizes a greater-than-majority voting requirement. Indeed, the Gulton court pointed out that the plaintiff conceded "it would be permissible . . . to require an 80 per cent vote for approval of [any] merger . . . . This would simply be calling for 'the vote of a larger portion of the stock.' "143 But the statute's apparent clarity is illusory. The history of statutory provisions that authorize supermajority requirements demonstrates that it is impossible to resolve the validity of shark repellent amendments without considering the decisionmaking roles of management and shareholders inherent in the structure of the corporation.

The origin of statutory provisions authorizing supermajority voting requirements lies in the recognition that:

the enabling-act type of statute, which became standard by the 1930's, tacitly assumed that the corporation would be one with a substantial number of shareholders.

The more difficult problems which the standard form of incorporation posed for the close-held firm concerned control. A minority investor in a close-held corporation was peculiarly vulnerable vis-à-vis the majority. . . . Thus individuals investing in a closeheld firm had reason to write into its organization requirements of unanimity or specially high requirements for a quorum or a deciding vote on critical matters, along with stipulations against dilution of their relative voting power. ... The standard incorporation acts were not responsive to these interests. ${ }^{144}$

The legislative response took the form of statutes like Delaware sec-

authority between management and shareholders reflected in the statute a relevant inquiry. The only possible reference to this subject comes in the last sentence before the opinion's final dispositional paragraph: "Moreover, various provisions of the corporation law confer discretion upon a board of directors in connection with mergers and other corporate transactions." Gulton, slip op. at 9 . The existence of managerial discretion in one area, however, may counsel against, rather than favor, similar discretion in a related area. See note 191 infra.

142. In these a supermajority vote is required regardless of the board of directors's approval and regardless of its composition.

143. Gulton, slip op. at 3.

144. J. HuRst, The Legitimacy of the Business Corporation in the United States 1780-1970, at 76-78 (1970); see, e.g., Hornstein, Judicial Tolerance of the Incorporated Partnership, 18 LAW \& CONTEMP. PROB. 435, 443 (1953); Manne, Our Two Corporation Systems: Law and Economics, 53 VA. L. REv. 259, 277 (1967). 
tion 102(b)(4) and its predecessors ${ }^{145}$ and section 143 of the Model Business Corporation Act and its predecessor, ${ }^{146}$ which authorized higher shareholder approval requirements than those specified in the statute.

While these statutory provisions are not on their face limited to close corporations, the legislative history is quite clear in pointing to the relationship between the needs of the close corporation and statutory authorization of supermajority voting requirements. For example, the drafting committee responsible for Model Act section 143 expressly states their belief that the "provisions authorized by section 143 are peculiarly for use by a close corporation." 147 Indeed, the numerous bibliographic references provided by the drafting committee deal exclusively with problems related to control in the close corporation. ${ }^{148}$ Similarly, leading treatises commenting on the corporation laws of major commercial states identify the plight of the close corporation as the motivation for statutory validation of supermajority provisions. With respect to section 204(a)(5) of the recently adopted California Corporations Code, ${ }^{149}$ Ballantine and Sterling state:

This . . reason, the protection of minority shareholders (especially in a close corporation) from adverse or oppressive actions by other shareholders, is the principal reason for permitting a corporation to include a super-majority vote requirement in its articles of incorporation. ${ }^{150}$

A similar conclusion emerges regarding the New York statute:

BCL $\S 616$ is one of the more important statutes designed to meet the needs of close corporations. In such corporations, sometimes referred to as "incorporated partnerships," minority shareholders

145. Del. Laws ch. $65, \S 5(11)$ (Revised Code 1935).

146. ABA-ALI MODEL BUS. CORP. ACT ANN. $\S 136$ (Supp. 1966). The change in numbering from $\S 136$ to $\S 143$ was not accompanied by substantive change.

147. ABA-ALI MODEL Bus. CORP. ACT ANN. 2D § 143, I 2 (comment to $\S 143$ ) (1971).

148. Id. \ 5.

149. CAL. CORP. CODE $\S 204$ (a)(5) (West Supp. 1981) allows articles of incorporation to include:

(a) Any or all of the following provisions, which shall not be effective unless expressly provided in the articles:

(5) A provision requiring, for any or all corporate actions (except as provided in Section 303, subdivision (c) of Section 708 and Section 1900) the vote of a larger proportion or of all of the shares of any class or series, or the vote or quorum for taking action of a larger proportion or of all of the directors, than is otherwise required by this division.

150. $1 \mathrm{H}$. Ballentine \& G. Sterling, California Corporation Laws $\$ 61.03$ (4th ed. 1979); accord, REPORT OF THE ASSEMBLY SELECT COMMTTTEE ON THE REVISION OF THE CORPORATIONS CODE 38 (1975) [hereinafter cited as SELEcT COMMITTEE REPORT]. 
often desire protection against ordinary majority rule. Superstatutory quorum and vote requirements are one of the most common means of obtaining such protection, since they provide the minority with the means by which it can veto majority action. ${ }^{151}$

And Professor Folk, the official reporter and adviser to the Delaware Committee on the Revision of the General Corporation Law, commenting with respect to Delaware section 102(b)(4) itself, states that "it is evident that high vote requirements are chiefly of interest to the small corporation." 152

My point is not that the statutory text, with or without its legislative history, makes supermajority provisions available only to close corporations. ${ }^{153}$ It is merely that the text alone cannot justify the Gulton court's construction authorizing use of shark repellent amendments in public corporations to deter tender offers. An adequate inquiry requires consideration of the appropriate roles to be assigned to management and shareholders in the context of a change in control, something that the text of provisions like section 102(b)(4) simply does not address.

A second case, Providence $\mathcal{E}^{\circ}$ Worcester Co. v. Baker, ${ }^{154}$ presents a similarly technical analysis of a corporate charter provision that, while not yet a common form of shark repellent amendment, has the potential to become one. ${ }^{155}$ In Providence $\mathcal{F}^{2}$ Worcester, the trustees in bankruptcy of the Penn Central Railroad were the largest stockholder in Providence \& Worcester Company ("P\&W"), owning 9,551 shares, or $28 \%$, of the outstanding stock. But P\&W's articles of incorporation contained a sliding scale that limited the voting rights of large holders to one vote per share for a shareholder's first 50 shares, but only

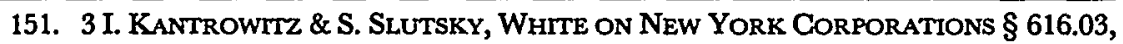
at 6-379 (13th ed. 1981) (footnotes omitted); see Hornstein, Analysis of Business Corporation Law, in N.Y. Bus. CORP. LAW app. 1, at 441, 454 (1963) ("The sections which 'accommodate' a statute primarily designed for public issue corporations to the needs of a close corporation are the following: Section 616 continues statutory authorization for the super-statutory shareholders' quorum and vote .....").

152. E. Folk, The New Delaware Corporation LaW 8 (1967).

153. The same legislative history that establishes the prominence of close corporation concerns also seems to contemplate a limited application of the provisions to public corporations. See Select Committee Report, supra note 150, at 38 (in addition to close corporation use, "a higher percentage requirement may be useful in non-close corporations particularly where special protection is desired for a certain class of shares"); accord, ABA-ALI MODEL BUS. CORP. ACT ANN. 2D $§ 143$, I 2 (1971) ("[T] statutory percentages in case of publicly held corporations, particularly where special protection is desired for a particular class of shares."). The question whether such limited use in public corporations is consistent with a structural approach is considered in note 229 infra.

154. 378 A.2d 121 (Del. 1977).

155. See Smith, supra note 6, at.10-11; Note, 4 DEL. J. CoRP. L. 154, 172 (1978). 
one-twentieth vote per share for additional shares. The articles also barred any shareholder from voting more than $25 \%$ of the outstanding shares, regardless of the number of shares held. ${ }^{156}$ These restrictions reduced Penn Central's potential $28 \%$ vote to approximately $3 \%$, and triggered a challenge to their validity. ${ }^{157}$

The validity of the provisions was determined on the field of pristine textual construction. The Court of Chancery began with section 212(a) of the Delaware General Corporation Law, which specifies that each share receives one vote unless a lawful charter provision otherwise provides. ${ }^{158}$ The court then examined section 151(a), which authorizes variation from the one vote per share rule-and therefore validates charter provisions adopted pursuant to section 212(a) - by allowing a corporation to have " 1 or more classes . . . or ... series of stock . . . which classes or series may have such voting powers, full or limited, or no voting powers . . . as shall be stated and expressed in the certificate of incorporation."159 The court concluded that the operative language of section 151(a)_-"which classes or series may have such voting powers"-allowed different classes and

156. A detailed statement of facts is set forth in the Chancery Court's opinion, 364 A.2d 838, 840-42 (Del. Ch. 1976), reo'd, 378 A.2d 121 (Del. 1977).

157. Note, supra note 155 , at $155 \mathrm{n} .8$, formulates the mathematics as:

50 votes for the first 50 shares plus 475 votes for the balance $(9,501$ divided by 20$)$. This total of 525 is further reduced by the provision that says no one stockholder may vote more than one-fourth of the outstanding stock. There are 35,000 shares outstanding, and one-fourth of that number is 8,750 . Since the trustees own more than one-fourth of 35,000 , their votes are computed only on 8,750 shares, reducing their voice to 485 votes ( 50 plus the dividend of 8,700 divided by 20 , or 50 plus 435 ).

(Citations omitted.)

158. DEL. CODE ANN. tit. 8, § 212(a) (1975) provides:

Unless otherwise provided in the certificate of incorporation and subject to the provisions of $\S 213$ of this title, each stockholder shall be entitled to 1 vote for each share of capital stock held by such stockholder. If the certificate of incorporation provides for more or less than 1 vote for any share, on any matter, every reference in this chapter to a majority or other proportion of stock shall refer to such majority or other proportion of the votes of such stock.

159. Id. § 151(a) provides:

Every corporation may issue 1 or more classes of stock or 1 or more series of stock within any class thereof, any or all of which classes may be of stock with par value or stock without par value and which classes or series may have such voting powers, full or limited, or no voting powers, and such designations, preferences and relative, participating, optional or other special rights, and qualifications, limitations or restrictions thereof, as shall be stated and expressed in the certificate of incorporation or of any amendment thereto, or in the resolution or resolutions providing for the issue of such stock adopted by the board of directors pursuant to authority expressly vested in it by the provisions of its certificate of incorporation. The power to increase or decrease or otherwise adjust the capital stock as provided in this chapter shall apply to all or any such classes of stock. 
series of stock to have different voting rights, but did not allow different voting rights among shareholders within one class of stock. ${ }^{160}$

The Supreme Court of Delaware reversed. The court found that the language of section 151 did not resolve the issue, ${ }^{161}$ and instead relied on what it viewed as the more explicit language of section 212(a). Noting that the latter section seemed to condition variation from the one share-one vote standard by cross reference to section 213 , which provides for determination of shareholders of record, ${ }^{162}$ the court concluded that the absence of a similar cross-reference to section 151(a) demonstrated that the language of that section did not limit the range of variation authorized by section $212(a) .{ }^{163}$ The court finished with an appeal to history, reasoning that since the Delaware legislature prior to 1901 had imposed voting restrictions on specially chartered corporations like those contained in the $\mathrm{P} \& W$ charter, "[i]t is reasonable to assume that if there was a legislative intent to bar such protective voting provisions, it would have been expressed in $\S 212(a) . " 164$

I am not persuaded by this analysis. Indeed, within the limits of the statutory language, I believe that the Court of Chancery con-

160. 364 A.2d at 847 .

161. We cannot agree that the answer to the problem presented is manifest and explicit on the face of $\S 151$ (a). The language of $\S 151$ (a), standing alone, neither permits nor prohibits the type of voting restrictions here challenged, either explicitly or by necessary implication. The statutory language may be read as Penn Central and Chancery Court view it; or it may be read as P\&W views it. It follows from such ambiguity that our task is one of statutory construction.

378 A.2d at 122.

162. Section 213 is titled "Fixing date for determination of stockholders of record," and does no more than specify the date for determining ownership for purposes of voting at a shareholders' meeting. DEL. CODE ANN. tit. 8, § 213 (1975).

163. Under $\S 212(a)$, voting rights of stockholders may be varied from the "one share-one vote" standard by the certificate of incorporation, subject only "to the provisions of $\S 213$ " of the Corporation Law. It is significant, we think, that $\S 212$ (a) was not made expressly subject to the provisions of $\S 151$ (a) in a similar manner. The absence in $\S 212$ (a) of such similar cross reference to $\S 151(a)$ is, in our judgment, indicative of the absence of any legislative intent to prohibit, by $\S 151(\mathrm{a})$, charter restrictions upon stockholders' voting rights such as are under challenge here.

378 A.2d at 123 (citations omitted). The court's argument with respect to the presence or absence of a cross-reference in $\S 212(a)$ is, frankly, silly. The obvious purpose of the crossreference to $\S 213$ is to make it clear that the shareholders entitled to "one vote for each share" under § 212(a) are those shareholders who own the shares on the record date fixed pursuant to $\S 213$. It is hardly likely that the absence of a cross-reference to any other section establishes the irrelevance of the rest of the statute for construction of other portions of §212(a).

164. Id. at 124. 
struction clearly has the better of it. But no matter what one thinks about the comparative ambiguity of sections 151 (a) and 212(a), it is undeniable that the supreme court never confronted or even acknowledged the central inquiry necessary to resolve the validity of the P\&W voting structure: What was the provision-which the court expressly referred to as "protective"165_designed to protect?

As the Delaware Supreme Court recognized, voting restrictions like the one in the $\mathrm{P} \& \mathrm{~W}$ articles were common among nineteenthcentury corporations. At that time general incorporation statutes, available to all who satisfied essentially formal requirements, were not widespread; incorporation largely remained an act of the sovereign requiring a special charter granted by the legislature. ${ }^{166}$ The principal beneficiaries of legislative charters were special action franchises-often in the character of public utilities. ${ }^{167}$ Public concern over the concentration of power in such special action franchises, although balanced by recognition of the economic utility of the corporate form, led to restrictions on legislatively chartered corporations, including the kind of voting restriction in the P\&W articles. ${ }^{168}$ In the nineteenth-century view, if economic power was to be centered in the corporation, it was necessary to prevent individuals from exploiting that centralization through ownership of a majority of a corporation's shares. ${ }^{169}$ This was particularly the case with transportation companies such as $\mathrm{P} \& \mathrm{~W}$, originally a railroad. As the Court of Chancery noted, the restrictive voting scheme at issue was imposed in the original legislative charter granted by the legislatures

165. Id.

166. The development of the incorporation process, from special charters to general incorporation statutes, is traced in, e.g., A. BERLE \& G. MEANS, THE MODERn CORPORAtion and Private Property 127-38 (1932); R. Hessen, In Defense of the CorporaTION 22-33 (1979); J. HURST, supra note 144, at 13-111.

167. J. HuRST, supra note 144 , at 17 , reports that of the 317 legislative charters granted in the United States between 1780 and 1801, two-thirds were for transportation companies, $20 \%$ for banks and insurance companies, $10 \%$ for water and other local service companies, and only $4 \%$ for miscellaneous purposes. Of the 2,333 corporations chartered by the Pennsylvania legislature between 1790 and $1860,64 \%$ were for transportation companies, $18 \%$ for financial companies, and $6 \%$ for local utilities.

168. $2 \mathrm{~J}$. Davis, Essays in the EARLIER History of AMERICAN Corporations 3-33 (1917); E. DODD, AMERICAN BUSINESS CORPORATIONS UNTIL 1860, at 195-201, 245, 250, 259-60, 328 (1954); J. HuRST, supra note 144, at 44-164.

169. J. DAVIS, supra note 168; E. DODD, supra note 168; Ratner, The Government of Business Corporations: Crilical Refections on the Rule of One Share, One Vote, 56 CORNELL L. REV. 1, 46 n.168 (1970) (restrictions of the type contained in P\&W charter "were more prevalent in the general and specific laws relating to 'quasi-public' corporations, such as banks and transportation companies than they were in the laws relating to manufacturing companies"). 
of Rhode Island and Massachusetts in $1844 .{ }^{170}$ Indeed, in 1836, the Massachusetts legislature had adopted legislation requiring provisions of this sort in all subsequent railroad charters for the precise purpose of limiting "[c]oncentration of control."171

In short, the provisions that the Delaware Supreme Court upheld as a means of enshrining a concentration of control in management were originally intended to prevent any concentration of control. They reflected a concern not for the well-being of minority shareholders, but for the community the corporation served. Neither the text of the Delaware statute nor its "legislative history" is directed at the allocation of responsibility between management and shareholders. The court's validation of the $P \& W$ provision without considering that question is simply an exercise in formalism.

The lesson of Gulton Industries and Providence $\mathcal{E}^{\circ}$ Worcester is straightforward: The language of a typical corporate statute does not, in itself, provide a complete description of how the corporate entity functions. The public corporation is an artificial "person," an intricate composite of the interaction both between its constituentsamong whom are shareholders and management-and between the corporation and the competitive environment in which it functions. ${ }^{172}$ The corporate statute does no more than create the entity's skeleton. Resolution of the appropriate allocation of responsibility between management and shareholders with respect to changes in corporate control requires an understanding of the variety of relationships that envelop the statutory skeleton.

\section{A Strugtural Approach to the Validity of Shark REPELLENT AMENDMENTS}

I have previously described the structure of the modern public corporation, including statutory and market aspects, with particular emphasis on the allocation of authority between management and shareholders. ${ }^{173}$ I argued that we should evaluate the validity of postoffer defensive tactics by reference to that structure and to the relationship between management and shareholders that it dic-

170. 364 A.2d at 841.

171. E. DODD, supra note 168 , at $327-28$.

172. For an attempt to describe the manner in which the corporation interacts with and responds to its environment by means of a formal feedback model, see Williamson, Corporate Control and the Theory of the Firm, in ECONOMIC POLIGY AND THE REgulation OF CoRpoRATE SECuRITIES 281-336 (H. Manne ed. 1969).

173. Gilson, supra note 2, at $833-40$. 
tates. ${ }^{174}$ That structure is equally relevant to the validity of preoffer shark repellent amendments, since these explicitly alter even the formal relationship between management and shareholders regarding changes of control. Thus, their consistency with the corporate structure should determine their validity; the outline of that structure bears restatement.

At the core of the structure of the modern public corporation are the benefits and costs resulting from the separation of ownership and management. Benefits from specialization, and from elimination of the transaction costs inherent in management by a multitude of shareholders, make this separation desirable; ${ }^{175}$ managerial discretion to favor itself, unavoidably resulting from this separation, accounts for the costs. ${ }^{176}$ The remainder of the corporate structure, consisting of market, judicial, and statutory elements, forms a coherent pattern that operates to minimize management incentives to exploit its discretion for its own benefit at the expense of the shareholders. The specter of business failure threatens both the shareholders' investment and managers' jobs, thereby constraining managerial discretion to operate inefficiently. ${ }^{177}$ Similarly, poor market performance by the corporation reflects badly on the skills of its managers, reducing the value of the managers' human capital in the employment market just as it reduces the value of the shareholders' investment in the capital market. ${ }^{178}$ Market constraints thus cause management and shareholder concerns for efficiency to parallel one another closely, despite the separation of ownership and management. As a result, there is little need for ex post judicial review of management efficiency-a conclusion consistent with the substance, if not the rhetoric, of judicial development of the duty of care and the business judgment rule. ${ }^{179}$

In contrast, similarly effective market constraints do not limit

174. Id. at $845-48$.

175. Id. at 834; see, e.g., Anderson, Conficts of Interest: Efficiengy, Faimess and Corporale Structure, 25 U.C.L.A. L. Rev. 738, 778-79 (1978); Clark, Vote Buying and Corporale Law, 29 CASE W. RES. L. REV. 776, 779 (1979); Heymann, The Problem of Coordination: Bargaining and Rules, 86 HARV. L. REV. 797, 831-33 (1973).

176. See Gilson, supra note 2, at 835-36; see also Alchian \& Demsetz, Production, Information Costs, and Economic Organization, 62 AM. ECON. REv. 777 (1972); Fama, supra note 74, at 296; Jensen \& Meckling, supra note 65, at 308-10.

177. Gilson, supra note 2, at 837-38; see, e.g., R. POSNER, supra note 65, at 302; R. WINTER, supra note 127 , at 18.

178. Gilson, supra note 2, at 837-38; see Fama, supra note 74; see also R. POSNER, supra note 65 , at 302 ; Werner, supra note 74 , at 389 .

179. Gilson, supra note 2 , at $822-24$. 
management's discretion to self-deal-to allocate to itself too much of the corporate income stream-in an efficiently operating corporation. Here, I argued, the legal system compensates for this failure by imposing a substantive constraint - the duty of loyalty, whose discharge is measured by the traditional fairness test. ${ }^{180}$

The fairness test's value is that it provides a largely objective and predictable constraint on management's ability to favor itself in corporate transactions. Management will be held to terms which would be commercially reasonable in an arm's-length transaction and which can be determined, albeit inexactly, by recourse to comparable market transactions and appraisals. Where the method by which management favors itself is more subtle and therefore lacks a ready market reference-e.g., a decision to use funds for acquisitions rather than dividend payments because of a managerial desire for the stature associated with running a larger corporation-a "fairness" standard provides little guidance for judicial review. Another marketthe market for corporate control-constrains these more subtle exercises of managerial discretion to self-deal, thus filling the gap left by the unavoidable shortcomings of the corporate structure's legal component. ${ }^{181}$ The reduced value of the corporation's stock reflects management deviation from practices maximizing shareholder wealth. When a potential offeror determines that the corporation is worth more to it after displacing nonmaximizing management ${ }^{182}$ than the price (including transaction costs) of obtaining control, management will be displaced. More important, the very threat of displacement operates as a constant check on managerial behavior. ${ }^{183}$

For that threat to have substance, however, there must be an effective mechanism by which incumbent management may be displaced. It is in this context that the tender offers and shark repellent amendments take on their critical role in the corporate structure. Of the four means to secure control of a public corporation, twomerger and sale of assets-require the approval of the target board of directors and, therefore, do not present a realistic threat of forcible

180. Id. at $839-40$.

181. Id. at $841-45$.

182. I include within the term "nonmaximizing management" those who manage corporations which lack the financial or other opportunities necessary to achieve efficient operation, as well as those whose failings reflect their own lack of skill. This distinction is intended to allow for both acquisitions based on expectations of synergy and those based on eliminating incompetency. See id. at 853 n.119, 872-74. 1197.

183. This point is well developed in Easterbrook \& Fischel, supra note 13, at 1169-74, 
displacement. ${ }^{184}$ Because of the advantages inherent in incumbency, a third means, the proxy contest, is an unattractive, although not entirely unavailable, mechanism. ${ }^{185}$ The tender offer, made directly to shareholders without the need for management cooperation, stands out as by far the best available mechanism to effectuate the market for corporate control. ${ }^{186}$ But for a tender offer to serve this end there must be direct access to target shareholders without management interference. ${ }^{187}$ It is in this context that a structural approach considers the validity of shark repellent amendments.

The intended result of a carefully crafted group of shark repellent amendments is to make a tender offer impossible without management consent. ${ }^{188}$ Recall, for example, that the supermajority vote requirement in Gulton Industries applied to any transaction with a 5\% shareholder unless incumbent management had consented to the transaction before the shareholder had acquired its position. ${ }^{189}$ At the same time, common exceptions in shark repellent amendments suspend their operation if incumbent management approves the transaction. ${ }^{190}$ The effort is to limit access to shareholders through a tender offer just as the corporate statute limits access to shareholders with respect to a merger or sale of assets: A tender offer is intended to be impossible without the incumbent management's approval.

This result is equally inconsistent with the structure of the modern public corporation whether it occurs before a tender offer, through shark repellent amendments, or afterwards through other defensive tactics. Shark repellent amendments that give management the same ability to block tender offers as the corporate statute gives with respect to mergers and sales of assets result in management's effective monopoly on corporate control. The threat of displacement will then provide little constraint on management behavior. Management will relinquish control only when the benefits to it from the proposed transaction exceed the value of its retaining discretion. Shark repellent amendments eliminate an essential means by which the corporate structure-ideally a coherent frame-

184. Gilson, supra note 2 , at 843 .

185. Id.

186. "The market for corporate control is crucial to the corporate structure because neither other markets nor a fiduciary 'fairness' standard effectively constrains some forms of management self-dealing . . . . In turn, the tender offer is crucial because no other displacement mechanism is available without management cooperation." Id. at 845-46.

187. Id. at 875-81.

188. See text accompanying notes $18-63$ supra.

189. See text accompanying note 133 supra.

190. See text accompanying notes $43-45$ supra. 
work of statutory, judical, and market components-constrains managerial discretion. They are therefore invalid. ${ }^{191}$

Against this backdrop, the argument proffered by the Delaware Supreme Court in Gulton Industries - that the inclusion of authority for a supermajority vote in a statutory laundry list of permissible charter provisions ${ }^{192}$ legitimizes shark repellent amendments-is simply untenable. The allocation of responsibility between management and shareholders with respect to changes of control, both in the statute itself and through market constraints, is too critical to the corporate structure to allow fundamental alteration by so facile an analysis.

While the argument establishing the invalidity of shark repellent amendments is now clear, two problems remain. First, why should we prohibit provisions that have been approved by a majority of the shareholders? After all, if the shareholders did not prefer the new role assigned to management, they could have voted against it. Second, as a practical matter, how do we identify the types of amendments the structural argument has rendered invalid?

\section{The Nagging Question: Why Do SHAREHOLDERS APPROVE?}

I have argued that shark repellent amendments are inconsistent with the corporate structure established by typical corporation statutes, associated legal rules, and the markets in which the corporation and its constituents participate. One must wonder, however, why the issue arises at all. The structure of the corporation has as its central logic the control of management's discretion to benefit itself at the

191. I have previously demonstrated that management control over mergers and sales of assets, as is provided by the typical corporate statute, not only is consistent with unlimited shareholder access to tender offers but, indeed, requires it. Because corporate acquisitions are complicated transactions requiring substantial skills to negotiate, rational shareholders would prefer that management approve a transaction before they devote their time to the proposal. This, of course, is precisely the procedure that the typical corporate statute prescribes for mergers and sales of assets. See, e.g., CAL. CORP. CODE $\$ \$ 1001$ (sale of assets), 1101 (merger) (West 1977 \& Supp. 1981); DEL. CODE ANN. tit. 8, §§ 251 (merger), 271 (sale of assets) (1975 \& Supp. 1980); ABA-ALI MODEL BUS. CORP. ACT ANN. 2D $\$ \$ 71$ (merger), 79 (sale of assets) (1971). The problem, however, is keeping management from abusing this discretion by, for example, rejecting an offer favorable to the shareholders, out of the desire to remain in control. The tender offer provides this necessary check. If management abuses its discretion by recalcitrant negotiation, then the offeror may bypass management and go directly to the shareholders by means of a tender offer. Consistent with this conclusion, the typical corporate statute gives management no explicit role in tender offers. See Gilson, supra note 2, at 845-52.

192. See text accompanying notes $136-38$ supra. 
expense of shareholders. The injury to shareholders resulting from the use of shark repellent amendments to circumvent the constraints imposed by the corporate structure seems direct and immediate: Shareholders are prevented from selling their shares at a price higher, and often much higher, than they could otherwise obtain in the market. ${ }^{193}$ If the adoption of shark repellent amendments causes the market to lower its estimate of the value of the corporation's stock because of the resulting increase in management's discretion to selfdeal, it will be precisely those shareholders voting for adoption who bear the cost. ${ }^{194}$ But since shareholders' interests are directly implicated, why need we be concerned with shark repellent amendments at all? Management cannot impose these amendments on shareholders; the shareholders must approve them by a majority vote. Why not simply rely upon their self-interest to protect their own and society's interest without regulatory intervention? Is there any reason to believe that shareholder voting does not adequately protect shareholder interest in access to the best price, and protect society's interest in an efficient allocation of resources?

One answer might be that shareholders are irrational, that by voting to adopt shark repellent amendments, they consciously choose a course that is less favorable than the available alternatives. But this explanation is inconsistent with the central premise of modern financial theory-that shareholders invest in securities to increase their wealth-and its corollary that a greater return is preferable to a lesser return, given equivalent risk. ${ }^{195}$ While one may point to circumstances where shareholders may seem to reduce their wealth by rejecting a higher price, the apparent irrationality of this behavior more likely reflects an overly narrow concept of wealth on the part of the observer rather than shareholder failure to maximize. For example, consider a shareholder who operates a tavern across from the manufacturing facility of a target corporation. If the offeror would close the facility if the offer is successful, the shareholder's overall wealth may be increased by forgoing the offered premium because of the effect of the offer's success on the value of the shareholder's other

193. While recent measurements of the size of tender offer premiums vary, the size of the premium is uniformly quite substantial. See, e.g., Bradley, supra note 94 , at 345-46, 348 (average premium of $49 \%$ ); Chatlos, The $S E C$ vs. investors on tender offers, HARV. Bus. REV., Sept.-Oct. 1978, at 6, 7 (72\% for unfriendly offers).

194. See note 65 supra.

195. See, e.g., W. Sharpe, Portfolio Theory and Gapital Markets 20-33 (1970); Modigliani \& Pogue, An Introduction to Risk and Retum, FIN. ANALYSTS J., Mar.-Apr. 1974, at $68,73$. 
assets. ${ }^{196}$

While shareholders are not irrational, they may be ignorant. Passive investors may not understand the consequences of the shark repellent proposal. In that case, shareholder "apathy"-as evidenced by voting with management even though an informed analysis would recommend the opposite course-is understandable. Shareholder participation in an election reflects a calculus only part of which relates to the particular matter that is the subject of the vote. The goal of the rational shareholder is to minimize the total of offsetting costs. On the one hand, serious participation in corporate voting requires the shareholder to invest the time and attention necessary to review and understand the proxy materials. If the proxy statement information is inadequate, ${ }^{197}$ the shareholders must incur additional costs to obtain the information necessary to an informed decision. On the other hand, there are the costs of nonparticipation-the costs to the shareholder if a proposal is adopted which is not in the shareholder's interest. ${ }^{198}$

The problem may be illuminated by a simple example. Suppose shareholders are asked to ratify the selection of the corporation's outside auditor. ${ }^{199}$ Against the costs of making a meaningful evaluation of management's selection, the shareholders must balance the costs that they might have to bear if, because of lack of interest, management gets its way: What damage could be done if management were given discretion to choose the auditor?

Put in this fashion, a shareholder might rationally conclude to vote with management and not even read the proxy disclosure con-

196. For a description of the "hometown vote" phenomenon, see Buford, Amending the Corporate Charter, 32 BuS. LAW. 1353, 1355 (1977). A tender offer can have "consumption" as well as capital gains effects. See Grossman \& Stiglitz, On Value Maximization and Altemative Objectives of the Firm, 32 J. Fin. 389 (1977). The point can be generalized. Where corporate decisions have an impact on shareholders' utility in ways other than through the value of their stock, profit maximization by the corporate entity may not be the most desirable production set for them. See Hirschleifer \& Riley, The Analytics of Uncertainty and Information-An Expository Survey, 17 J. Econ. LrT. 1375, 1393-94 (1979). For the relevance of this point to construction of the corporate statute, see text accompanying notes 220-29 infra.

197. See note 7 supra.

198. See generally J. Buchanan \& G. Tullock, The Calculus of Consent 43-62 (1965); A. DOWNS, AN ECONOMIC ThEORY OF DEMOCRACY 265-76 (1957). In a corporate context, see, e.g., Clark, supra note 175; Fischel, supra note 9, at 30-31.

199. While there is no legal requirement that management seek shareholder approval of the selection of an independent accountant, $M$. EISENBERG, supra note 46, at 196-98, 205-09, approval is nonetheless increasingly sought. Hawes, Slockholder Appointment of Independent Audilors: A Proposal, 74 Colum. L. REv. 1, 21 (1974). For the disclosure required in this setting, see item 8 of Schedule 14A, 17 C.F.R. $\$ 240.14 a-101$ (1981). 
cerning the selection of an auditor. The cost of determining which of the prominent accounting firms is the "best" for the corporation is a time-consuming process that management has presumably already completed. Further, management has an interest in the accuracy and professionalism of the auditors consistent with the interests of the shareholders-for example, relations with creditors and the capital market depend in part on a belief in the integrity of the corporation's financial statements. ${ }^{200}$ Moreover, the auditors themselves, whose professional success depends on a continued reputation for independence, have an interest in making sure that the audit process is effective. ${ }^{201}$ In sum, the real costs of participation are likely to outweigh the potential costs of allowing management its choice of auditor without further examination.

Speculating on the character of a rational shareholder's analysis of proposed shark repellent amendments is more complicated. A sophisticated shareholder may recognize that, because it relates to corporate control, management's proposal may be based on interests that diverge from his own. Thus, there will be little cost to concluding that the proposal warrants more careful consideration. However, because other shareholders may be less sophisticated, the cost of informing them of this conflict must also be considered. That is, one must add the cost of a proxy fight to educate others, which probably will be borne entirely by the individual shareholder, ${ }^{202}$ to the cost of educating oneself if a serious challenge to management is to be mounted. Thus, sophisticated institutional investors, who likely incur no information costs in concluding that shark repellent amendments are not in their interests, may nonetheless decide not to mount a serious challenge to management on the matter.

Such a conclusion would, of course, require balancing of the potential costs to shareholders that would result if the shark repellent amendments were approved. The elements which would enter into that decision are the probability that a tender offer would be made,

200. See, e.g., Beaver, The Nature of Mandaled Disclosure, in House COMM. ON INTERstate and Foreign COMmerce, 95Th CONG., 1st Sess., Report OF the Advisory Comm. On Corporate Disclosure to the Securities and Exchange Comm'n 618, 637-39 (Comm. Print 1977).

201. See, e.g., Benston, The Market for Public Accounting Services: Demand, Supply and Regulation, 2 ACCT. J. 2 (1979); Ng, Supply and Demand for Auditing Services and the Nature of Regulations in Auditing, in "The Accounting Establishment" In Perspective 99 (S. Davidson ed. 1978); R. Watts \& J. Zimmerman, The Markets for Independence and Independent Auditors (Graduate School of Management Working Paper, University of Rochester) (July 1980).

202. See Clark, supra note 175, at 781-82; Easterbrook \& Fischel, supra note 13, at 1181; Gilson, supra note 2, at 843 . 
whether management really would use the amendments to perpetuate its control, and, perhaps most important, whether the shark repellent amendments really would have a significant deterrent effect. If, ex ante, the probability of an offer is low, or management appears to be unwilling to fight, or the amendments are not likely to be very effective, then management's action may not be worth challenging even if the costs of challenge are low.

Interestingly, the observed behavior of institutional investorsprobably the best surrogate for the "rational investor"-appears to be roughly consistent with this analysis, if one assumes that shark repellent amendments are not very effective. Since institutional investors need not incur significant information costs to conclude that shark repellent amendments do not serve their interests, one would expect that such investors would at least vote against these amendments. The available data are in accord with this prediction. The Securities and Exchange Commission's 1971 Institutional Investor Study reported that of all voting subjects, shark repellent amendments generated the second greatest incidence of antimanagement voting by institutional investors. ${ }^{203}$ The increase in the incidence of the shark repellent phenomenon, and the publicity associated with it in recent years, should have increased the likelihood of institutional investors casting negative votes on these amendments, a prediction confirmed by a survey of the voting behavior of 92 institutional investors during the 1980 and 1981 proxy seasons. ${ }^{204}$ Of the 31 banks surveyed (including 12 of the 20 largest commercial banks), 19 voted against supermajority requirements for second-step mergers as a matter of policy and the others specifically reviewed each such proposal. ${ }^{205}$ At the same time, I am aware of no instance in which an

203. 5 Securities and Exchange Commission, Institutional Investor Study, H.R. Doc. No. 64, 92d Cong., 1st Sess. 2754 (1971) [hereinafter cited as InSTITUTIONAL INVESTOR STUDY].

204. J. Heard, Voting Policies of Institutional Investors on Corporate GOVERNANCE IsSUes (1981) (survey by Investor Responsibility Research Center).

205. Id at 14-16. The accuracy of the survey is confirmed by a prominent practitioner's recent statement that "[p]olicies in most of the major banks and most of the major funds call for automatic rejection of" shark repellent amendments. Mestres \& Gerlits, Tender Offers: Considerations for the Defense, in Eleventh ANNuAL Instrtute ON Securities ReguLATION 74 (1980) (comment of Joseph Flom). The survey did show substantial differences in voting patterns among different categories of institutional investors. While the voting of insurance companies and investment firms (including 7 of the 10 largest life insurance companies) was similar to that of banks (10 of 16 routinely opposed supermajority amendments), the 28 colleges and universities surveyed voted against management in large measure only on social policy resolutions. Four of the six public employee pension funds also routinely voted with management on such issues. J. HEARD, supra note 204, at 26-28, 31-34, 38-40. 
institutional investor went beyond simply voting against a shark repellent proposal and initiated a proxy fight. This result is consistent with a calculus calling for a negative vote, because information costs need not be incurred to reach that conclusion, while counseling against a proxy fight, because the limited damage anticipated from the adoption of the shark repellent amendments does not warrant its more substantial cost. ${ }^{206}$

The upshot is that shareholder voting cannot be relied upon to police management self-interest with respect to the adoption of shark repellent amendments. The conclusion that shark repellent amendments are invalid is not affected by shareholder votes that approve them.

\section{Identifying the InValid Provisions}

The conclusion that shark repellent amendments are invalid does not end our inquiry. To invalidate shark repellent amendments, we must first be able to identify them. To be sure, some varieties of shark repellent amendments-those creating barriers to second-step

206. To be sure, institutional investors appear to have voted in favor of shark repellent amendments for a substantial period of time when, it seems, they should have known better. As of 1971 institutional investors had voted in favor of most shark repellent amendments, INSTITUTIONAL INVESTOR STUDY, supra note 203, at 2754-55; it was a full 10 years before Mr. Flom could state that policies of "automatic rejection" had been adopted, and even then disparities existed among institutional investors, see note 205 supra. The explanation for the lengthy period necessary to assimilate the notion that one should not always vote with management, it seems to me, is likely to be anthropological, rather than economic, in the sense of being based on an examination of the mechanisms by which widely held group norms-in our case those of the investment community-are changed. While one can describe the process in economic terms-i.e., change came slowly because anyone opposing management would appear to be a troublemaker, would run the risk of sanction within the community, and thus would because of self-interest move cautiously-the description does no more than restate the problem: Why did attitudes take so long to change; how did the change occur? Cf. Kelman, Choice and Utility, 1979 WIs. L. REv. 769, 784 ("Once the neo-classicists begin to introduce 'psychic costs' to preserve their tautology, the choice model breaks down altogether."). Other examples of this quandary are also present in the tender offer arena. Why did it take so long for the major investment banking firms to be willing to participate in hostile takeovers? Not until 1975 did Morgan Stanley, the most conservative investment banker of all, first participate in such a transaction. M. SALTER \& W. WEINHOLD, supra note 32, at 217-30. Why does Goldman Sachs reportedly still refuse to represent an offeror making a hostile bid? The Making of the Megamerger, ForTuNe, Sept. 7, 1981, at 58, 60.

One can, however, imagine strategies that counsel in favor of promanagement voting on shark repellent amendments if it is believed that the amendments are not likely to be effective. Management provides a source of valuable information to institutional investors which is not accessible to others, and its availability depends on a good relationship with management. If the promanagement vote is costless, then nothing is lost by currying management favor by a sympathetic vote. 
transactions and those compelling a "fair" price or compulsory redemption-are sufficiently self-identifying that no further inquiry is necessary. But some forms of amendment, principally those designed to impede transfer of control of the board of directors, can fulfill a legitimate purpose distinct from their role in deterring a tender offer. ${ }^{207}$ Of course, when potentially dual-purpose amendments are proposed following the making of a tender offer, the timing of the proposal itself serves as an identification mechanism. ${ }^{208}$ But shark repellent amendments are principally designed to deter an offer, not to respond to one already made. ${ }^{209}$ Thus, they are most often proposed before an offer is even on the horizon. In the absence of an existing offer which would serve to brand an illegitimate proposal, we need an identification mechanism that will not degenerate into the quagmire of intent analysis.

A workable solution to the identification problem for dual-purpose amendments grows out of the fact that shark repellent amendments are ineffective without a lock-up provision requiring a supermajority vote for amendment or repeal. Such a provision, combined with a simple majority requirement for initial adoption, allows a present majority to bind a future majority; in the case of a $90 \%$ supermajority amendment, a present $51 \%$ can bind a future $89 \%$. It is this ability to bind a future offeror's majority that gives the shark repellent concept its promise of deterrence. A simple way to separate legitimate from illegitimate dual-purpose amendments, then, is to focus directly on the lock-up provision. As long as a future acquirer of control does not have a more difficult task with respect to repeal or amendment than did management with respect to adoption, the amendment no longer has the potential to deter an offeror, and thus,

207. For example, cumulative voting can be an important means of securing minority board representation; classified boards are sometimes thought to provide continuity of management. See W. Cary \& M. Eisenberg, Cases and Material ON Corporations 258-61 (5th ed. 1980) (collecting arguments and authorities).

208. They would then fall within the prohibition of post offer defensive tactics. See Gilson, supra note 2, at 878-79.

209. There are examples of their adoption in the postoffer period. B.F. Goodrich resorted to their use against Northwest Industries in 1969 in one of the first major defensive efforts. O. Williamson, CoRPorate CONTROL AND Business BEHAVIOR 100-02 (1970). Much more recently, PSA proposed a package of shark repellent amendments, see notes 28-29 supra, following the accumulation of a significant block of stock by Harold Simmons. Although Simmons had not then announced a tender offer, the amendments were clearly directed at him and he waged an intensive proxy campaign against their adoption. They were approved by a very narrow margin, after which Simmons was bought out by the company. PSA Passage of Porcupine Amendments Is Cited for Valhi's Moves to Sell Holding, Wall St. J., Feb. 23, 1979 , at 14 , col. 2. 
should not be invalid under a structural approach. This neutralization can be accomplished by the simple requirement that shareholders approve amendments imposing a supermajority vote by a vote equal to or greater than that necessary for action under the amendment. Thus, for example, adoption of a $90 \%$ supermajority requirement for further amendment of a provision in the corporate charter would take a $90 \%$ vote of the shareholders. ${ }^{210}$

The adequacy of this identification mechanism-ignoring the substance of a dual-purpose amendment in favor of an effort to render the associated lock-up provision ineffective-turns on the results of two inquiries. First, does such a symmetrical vote requirement in fact eliminate any deterrent to an offeror as a result of the adoption of the substantive provision; and second, can the nontakeover goal of the amendment be accomplished without the ability to bind a future majority?

With regard to the first inquiry, the proposed identification mechanism is adequate but not perfect: Incumbent management retains something of an advantage, but not a very important one. To the extent that shareholders' voting calculus at the time of the shark repellent proposal favors going along with management, a subsequent offeror may be disadvantaged by having to face a supermajority requirement swollen by "rational apathy."211 But the problem is now of much less significance. Because the supermajority required can be no higher than the percentage of shareholders that originally approved it, those not returning their proxies at the time of approval no longer count as having been on management's side. Passive resistance therefore becomes effective, ${ }^{212}$ making it much less likely that management can secure enough votes to support a lock-up percentage high enough for management alone to block future repeal

210. This approach is consistent with that of the Michigan statute, MrCH. CoMp. LAwS $\S 450.1455$ (MICH. STAT. ANN. $\$ 21.200(455)$ (Callaghan 1974)), and similar to that of N.Y. BUS. CORP. LAW \$616(b) (McKinney 1963), although the latter requires only a flat twothirds approval regardless of the level of supermajority proposed. An amendment following the Michigan approach was recently proposed for the Model Business Corporation Act. Changes In The Model Business Corporation Act-Amendment Respecting Increases In Proportion Of Vote For Shareholder Approval, 36 Bus. LAw. 1899 (1981) (report of Comm. on Corp. Laws).

211. See A. Downs, supra note 198, at 265 (coining term "rational abstention'); text accompanying notes $193-206$ supra.

212. There have been examples of extensive passive resistance in connection with shark repellent amendments. For example, a package of amendments proposed by McGulloch Oil Corp. failed to secure the necessary $50 \%$ approval even though $94 \%$ of the proxies that were returned favored the proposal. McCulloch Oil Fails To Get Enough Votes For Antitakeover Plan, Wall St. J., June 19, 1980, at 30, col. 3. 
or amendment. ${ }^{213}$ Moreover, when the lock-up amendment is applied, the shareholders' voting calculus would tend to favor the offeror. For example, voting with a successful offeror to facilitate a second-step merger by allowing a change in board membership not only provides shareholders a way out of a minority position but, because the offeror bears the expense of the proxy process, does so without some of the participation costs which counseled against fighting management when the shark repellent amendments were proposed. In sum, little potential for deterrence remains and the proposed identification mechanism satisfies the first concern raised.

The second inquiry-whether the nontakeover value of dual-purpose amendments is reduced by the elimination of the present majority's ability to bind a future majority-also recommends the proposed identification mechanism. A rational individual's preference in setting the percentage approval required for group action turns on the balance between two types of costs. ${ }^{214}$ On the one hand, the individual must consider the costs that may be imposed on him by future group decisions he disagrees with-which decrease as the percentage required for approval approaches unanimity. ${ }^{215}$ On the other hand, the individual must also take into account the transaction costs associated with making any group decision at all-which increase not only as the number of people in the group increases, but also as the percentage required for approval increases. ${ }^{216}$ Viewed in this way, an individual has no reason to favor a decision rule that makes future decisions more difficult than choosing the decision rule itself unless the individual can predict future group action that will be more injurious to him than to other members of the group. In that event, a decision rule making future decisions more difficult-i.e., increasing the percentage vote for action to be taken with respect to

213. This distinction may be illustrated by an example. Assume that management itself controls $15 \%$ of a potential target's outstanding stock, and wishes to adopt shark repellent amendments that would require an $85 \%$ vote to amend or repeal. If a simple majority of the outstanding shares is required to adopt the supermajority requirement, and if all shares controlled by management are voted in favor of the amendment, management must secure the vote of only approximately $42 \%$ of the remaining shares in order to succeed. Alternatively, if an $85 \%$ vote were required to adopt the proposed amendment, management would need the votes of approximately $82 \%$ of the remaining shares. Indeed, if one imagines a proposal that establishes a supermajority requirement equal to the percentage of the outstanding shares voted in favor of it, an abstention reduces the maximum percentage possible as much as a vote against the proposal.

214. See generally J. BuchanaN \& G. Tullock, supra note 198, at 63-80.

215. Obviously, if each member of a group could veto any group decision, no action could be taken that was contrary to any member's interst. Id. at 64 .

216. Id. at 68-69. 
them-may be desirable. ${ }^{217}$ Applying this analysis in a corporate context, so long as a shareholder can assume that his future interests will be best served by that course of conduct which maximizes the collective wealth of shareholders, ${ }^{218}$ one shareholder's interests will not differ predictably from those of other shareholders, and decisions made by future shareholders present no greater danger than the choice of the decision rule itself. But when a shareholder can anticipate future decisions that affect him differently than other shareholders-as management can predict that its interests will differ from those of shareholders in the event of a takeover attempt-then a rule that binds a future majority will be desirable. ${ }^{219}$ This form of motivation, however, is precisely that which a structural approach identifies as invalid. In short, the inability to bind a future majority should not reduce the utility of supermajority requirements except for shark repellent purposes, exactly the result desired from an identification mechanism.

\section{Structural Limitations on the Enabling Concept}

Both the problem of statutory interpretation posed by shark repellent amendments and the structural approach that $I$ have offered to resolve it can be generalized. The corporate statutes of major commercial jurisdictions are commonly described as "enabling" in character; ${ }^{220}$ regulation of the relationships between corporate constituents intended to eliminate undesirable arrangements is forgone in favor of maximizing the freedom "to put the arrangements for the allocation of risk, control, profit, and residual ownership on a free contract basis."221 The general problem of statutory interpretation in this area is how literally to take that philosophy and, in turn, the language of the statute: Are there limits that should be imposed on

217. Id. at 78-79.

218. The basis for this assumption is discussed in the text accompanying notes 223-24 infra.

219. Technically, an additional condition must be met: The benefits from applying such a rule in these predictable future settings must outweigh the extra costs of the rule's application in all other decisions. Because it will be the shareholders who ultimately bear the extra transaction costs of inefficient decisionmaking rules, see note 65 supra, this condition should be satisfied for management with respect to shark repellent amendments.

220. See, e.g., Katz, supra note 114, at 179; Latty, supra note 17, at 601-02. The California Corporations Code is an exception. See R. Jennings \& R. Buxbaum, Cases and MATERIALS ON CORPORATIONS xv (5th ed. 1979).

221. Latty, supra note 17 , at 601 . At the other extreme is what has been termed the "paternal responsibility" approach, which seeks to identify and prohibit particular allocations of risk, control, and profit thought "to jeopardize responsible investment and management." Katz, supra note 114, at 180. 
the statute's apparently unrestricted invitation to private ordering? Broadly speaking, the courts have answered that question in fundamentally conflicting ways.

I have argued that the judicial response to shark repellent amendments has been an exercise in statutory literalism. Courts have read the statute strictly to allow management the freedom to alter substantially the allocation of authority between management and shareholders that is reflected in the remainder of the statute and in the structure of the corporation. This commitment to contractual freedom for public corporations stands in sharp contrast to the courts' historical approach to problems of close corporations. Efforts by shareholders of these corporations to organize their enterprises in ways that conflict with the statutory allocation of authority-for example, by shifting the locus of decisionmaking from directors to shareholders-were too often struck down in reliance on the same statutory literalism. ${ }^{222}$ The courts never recognized that strict application of the corporate statute resulted in different amounts of deference to the concept of contractual freedom. As a consequence, it was difficult to discern a consistent approach to accommodating the statute's language and philosophy.

The conflict in the primacy given the value of freedom of contract despite similar methods of statutory construction-in each case reaching the wrong result-derives from failing to consider the statute as only one part of the corporate structure and, therefore, failing to appreciate the fundamental differences between the structures of the entities under consideration. Supermajority vote requirementsthe critical element of shark repellent amendments-provide an example of this methodological failure.

I have argued that these provisions serve no justifiable role in the public corporation. ${ }^{223}$ Maximization of the corporation's profits by management best serves both society's interest in an efficient allocation of resources and the interests of the corporation's shareholders. Shark repellent amendments are invalid because they shelter management from the discipline of an important market mechanism encouraging profit maximization. In contrast, the structure of a close corporation allows for a beneficial role for supermajority provisions

222. See W. CARY \& M. EISENBERg, supra note 207, at 424-41 (tracing judicial response to shareholder agreements controlling discretion of board of directors); see also F. O'NEAL, Close CoRPORATIONS $§ 1.13$ (1971); Hornstein, supra note 144; Manne, supra note 144, at 283.

223. See text accompanying notes $173-92$ supra. 
even though they facilitate what, in a public corporation, would be nonmaximizing arrangements.

In the private setting, a critical premise of the structure of the public corporation-that both society and the shareholder are best served by maximizing the entity's profit-is simply incorrect. The accuracy of that premise depends on whether the only effect of the corporation's decisions on the shareholder is in the value of the firm. If that is so, shareholders will prefer profit maximization because, by definition, deviation from it can only make them worse off. ${ }^{224}$ While presumably satisfied in public corporations, this condition is clearly not satisfied in close corporations. Lawyers working with close corporations recognize that maximizing the shareholders' profit may not be the same as maximizing the corporation's profit; for example, employing a shareholder's brother-in-law, even if not an efficient decision, may provide more utility to the shareholder than the corporate income forgone because of hiring a less productive employee. In that setting, deviation from profit maximization should not presumptively raise the specter of misallocation of resources. Because of the ease of direct bargaining in private corporations-I'll take your brother-inlaw if you take mine-the result can be expected to reflect actual shareholder desires. The use of supermajority provisions to assure the continuity of such bargains is thus beneficial. ${ }^{225}$

This example illustrates that the structures of public and private corporations are fundamentally different. ${ }^{26}$ But the differences are significant only if the corporate enabling statute is construed in structural terms: how the statute should mesh with the nonstatutory relationships-market and others-which together determine the behavior of the entity, and which differ depending on whether the corporation in question is public, private, or somewhere in

224. See DeAngelo, Competition and Unanimity, 71 AM. ECON. Rev. 18, 23-24 (1981); Hirschleifer \& Riley, supra note 196, at 1393-94; see also Grossman \& Stiglitz, supra note 196, at 394 .

225. Prior to the adoption of specific enabling legislation of the sort relied upon in Gullon Industries, see text accompanying notes 144-53 supra, courts often relied upon the literal terms of the corporate statute to strike down supermajority requirements. See, e.g., Benintendi v. Kenton Hotel, Inc., 294 N.Y. 112, 60 N.E.2d 829 (1945); see generally W. CARY \& M. EISENBERG, supra note 207 , at $453-60$.

226. The courts, of course, have reached results consistent with this conclusion, albeit without careful articulation of their method of statutory interpretation. These results are considered in detail by Professor Karjala in a recent article arguing that judicial performance under general corporate statutes has reached a level such that separate close corporation statutes are no longer necessary. See Karjala, $A$ Second Look at Special Close Corporation Legislation, 58 TEx. L. REv. 1207 (1980). One does encounter occasional throwbacks, however. See Roach v. Bynum, 403 So. 2d 187 (Ala. 1981). 
between. ${ }^{227}$

A structural approach thus provides a method of coherently differentiating between types of corporations for purposes of interpreting the corporate enabling statute. ${ }^{228}$ Freedom of contract-the touchstone of the enabling concept-should be paramount in the private corporation setting. In the public corporation setting, the requirement of profit maximization and the existence of important market constraints on managerial behavior provide a basis for principles that appropriately limit freedom of contract. The same statute, in different settings, should yield different results, and the differences result not from the statutory language, but from principles derived from the nonstatutory aspects of the corporate structure. ${ }^{229}$

227. There has been increasing recognition that the quasi-public corporation-one with a dominant shareholder but with a public minority-presents problems different from those presented by either of the traditional corporate models. See, e.g., M. EISENBERG, supra note 46, at 275-316; Brudney \& Clark, A New Look al Corporate Opportunities, 94 HARV. L. REv. 997, 1045-60 (1981); Knauss, Corporate Govemance-A Moving Target, 79 Mich L. Rev. 479-87 (1981). In the context of this discussion, maximizing the dominant shareholder's profit may be different from maximizing the entity's profit, while entity profit maximization would be preferable for the public shareholders.

228. An approach of this sort is reflected in the recent efforts of Professors Brudney \& Clark, supra note 227 , to rationalize the corporate opportunity doctrine by explicitly distinguishing between three classes of corporations on the basis of what I have called structural attributes.

229. A structural approach to statutory construction should also allow making somewhat finer distinctions. While structural elements dictate a general limit on the range of freedom of contract in a public corporation, there may be some circumstances which nonetheless justify individual variation. Conflicts between classes of stock within a public corporation provide an illustration of this.

A common statutory pattern gives nonvoting preferred stock the right to vote on the acquisition of the corporation by merger, if the proposed merger will alter the rights, preferences, and privileges of the preferred. See, e.g., CAL. CORP. CODE § 1201 (a) (West 1975 \& Supp. 1981). The preferred is given no role, however, in business decisions concerning acquisition of assets by the corporation, regardless of the transaction's impact on preferred. The question is whether a corporation's articles of incorporation may prohibit the corporation from acquiring more than a specified amount of assets without preferred approval. The statute itself typically provides no clear resolution. But see id. § 204(a)(9) (authorizing charter provision requiring shareholder approval for any corporate action even if not required by the statute). On the one hand, the statutory allocation of decisionmaking authority gives preferred stockholders no role in such decisions; indeed, the statute largely limits even common holders to influencing these choices through their power to elect directors. On the other hand, the typical statute also offers a blanket invitiation to "any provision creating, defining, limiting and regulating the power of . . . any class of stockholders . . . if such provisions are not contrary to the laws of this State." DEL. CODE ANN. tit. 8, § 102(b)(1) (1975); see ABAALI MODEL Bus. CORP. ACT ANN. 2D § 54(h) (1971).

A structural analysis suggests that this contractual alteration in the statutory allocation of decisionmaking authority is valid even in a public corporation. While the presence of market incentives which reinforce management's obligation to maximize profit on behalf of the common shareholders eliminates the need for common shareholder involvement in such deci- 


\section{CONCLUSION}

\section{Shark repellent amendments pose two challenges for a structural}

sions, see Gilson, supra note 2 , at $833-45$, those same incentives justify allowing preferred shareholders to bargain for a broader role. Indeed, profit maximization-a cornerstone of the structure of the public corporation-is precisely what the preferred shareholders require protection against.

For this purpose, assume a class of preferred which has a fixed dividend and liquidation preference, and a right to elect a majority of the directors if preferred dividends are not paid. See Buxbaum, Preferred Stock-Law and Draflsmanship, 42 GALIF. L. REv. 243, 290-98 (1954). The rights of the common shareholders then approximate a form of call option: the right to acquire an asset at a specified price. If the value of the corporation exceeds the present value of the preferred dividends, those dividends will be paid and the common will thus exercise its option to "keep" the corporation; if it does not, dividends will not be paid and the preferred holders will take control and run the corporation for their own advantage. See generally Black \& Scholes, The Pricing of Options and Corporale Liabilities, 81 J. POL. EcoN. 637 (1973). The factors that determine the value of the common shareholder's option demonstrate that profit maximization from the perspective of the common works to the disadvantage of the preferred. Research into the determinants of option pricing has shown that, other things being equal, the value of a call option increases with the variability in the value of the asset subject to the option. See, e.g., R. Brealey \& S. Myers, Principles of Corporate Finance 433-41 (1981); J. VAN HORNE, supra note 32, at 80-98. The intuition underlying this relationship is that while greater variability in potential value increases both the option holder's potential gain and loss relative to the exercise price, the gain is unlimited, while the loss cannot exceed the price paid for the option; if the underlying asset is worth less than the exercise price, the option holder simply will not exercise it, thereby limiting the loss to the cost of the option.

In this context, the price paid for the option is the common's investment, and the exercise price is the preferred's dividend, which is set to reflect the market's evaluation of the variability in the corporation's value. It should be apparent that once the terms of the option have been set-once the preferred stock is issued at a specified dividend rate-the common has an incentive to increase the variability of the corporation's future value. The resulting increase in potential value goes entirely to the common because the preferred's return is fixed, while the preferred participates in the increase in potential loss. The upshot is that the value of the common is increased and the value of the preferred is decreased.

In short, the common shareholders and their representatives, management, have an incentive to make the corporation's business more risky-to increase the range of future values-once a fixed preferred dividend has been issued. One way to accomplish this is by reinvesting funds previously committed to low risk investments in riskier assets. This, of course, is precisely the type of transaction that the hypothetical charter provision would prohibit without preferred consent, and it presents the same problem lenders have responded to through the use of bond covenants. See, e.g., Jackson \& Kronman, Secured Financing and Priorities Among Creditors, 88 Yale L.J. 1143, 1149-58 (1979); Smith \& Warner, On Financial Contracting: An Analysis of Bond Covenants, 7 J. FIN. ECON. 117, 125-31 (1979).

A structural approach to the problem of statutory construction would thus allow such a charter provision. The combination of market incentives to maximize the value of the common stock, and the statutory allocation of decisionmaking power, which together justify the general restriction of freedom of contract in a public corporation, in this setting create incentives for the common to make choices that disadvantage the preferred. Recognition of these nonstatutory influences counsels in favor of allowing the preferred to protect themselves by bargaining for limits on the ability of those representing common shareholders to behave opportunistically.

It is worth noting that this analysis explains otherwise cryptic references in the legislative 
approach to corporations: whether such an approach can deal with the seemingly express statutory authorization of the critical aspect of the shark repellent approach, and whether that effort yields broader insights into the value of a structural approach to construction of the corporate statute. On a specific level, I think that structural analysis clearly demonstrates that the corporate statute should be construed not to authorize shark repellent amendments-provisions that are in direct conflict with the allocation of authority between management and shareholders reflected in the structure of the modern public corporation. Gulton is simply wrong. On a more general level, a structural approach provides a coherent approach to limiting the broad invitation to private ordering reflected in the enabling form of corporate legislation. Focusing on such nonstatutory aspects of the corporate structure as the congruence between maximizing shareholder wealth and maximizing corporate profits promises to be an attractive alternative to the statutory myopia exemplified by decisions like Providence $\mathcal{E}^{2}$ Worcester.

history of statutory provisions like DEL. CODE ANN. tit. $8, \S 102(\mathrm{~b})(4)$ (1975) to their value in public corporations. See note 153 supra. 